\title{
Analysis of Solved Examples in Mathematics Textbooks Regarding the Use of Geometric Habits of Mind
}

\author{
Zeynep Bahar Erşen ${ }^{a}$, Buket Özüm Bülbül ${ }^{b}$ and Mustafa Güler ${ }^{c}$ \\ ${ }^{a}$ Selçuk University, Faculty of Education, Konya/Turkey (ORCID: 0000-0002-7928-2535) \\ ${ }^{\mathbf{b}}$ Manisa Celal Bayar University, Faculty of Education, Manisa/Turkey (ORCID: 0000-0001-9610-7053) \\ ${ }^{\mathbf{c}}$ Trabzon University, Fatih Faculty of Education, Trabzon/Turkey (ORCID: 0000-0002-4082-7585)
}

Article History: Received: 30 November 2020; Accepted: 2 February 2021; Published online: 5 February 2021

\begin{abstract}
This study aimed to examine the solved examples used in polygons and measurement of area subjects in mathematics textbooks approved to be taught in the 2020-2021 academic year in terms of geometric habits of mind. In this context, a total of ten mathematics textbooks, including two fifth grade, three sixth grade, two seventh grade, and three eighth grade, were examined. The solved examples in the textbooks were subjected to document analysis for the following habits; reasoning with relationship, thinking and generalizing special cases, investing of invariants, and exploration and reflection. Regarding the study results, the solved examples of the fifth, sixth and seventh grades mostly used reasoning with relationship, exploration and reflection habits, whereas the examples of eighth grade were observed to include investing of invariants in addition to these habits. Besides, there are examples based on computer software at every grade level, but it was concluded that such examples are best used in the eighth grade to address the geometric habits of mind. Some suggestions have been made based on the results obtained.
\end{abstract}

Keywords: Geometric habits of mind, mathematics textbook, solved examples

DOI:10.16949/turkbilmat.850882

\begin{abstract}
Öz: Bu çalışmada 2020-2021 öğretim yılı itibariyle okutulması kabul edilmiş matematik ders kitaplarının çokgenler ve alan ölçme konularında kullandıkları çözümlü örneklerin geometrik düşünme alışkanlıkları kapsamında incelenmesi amaçlanmıştır. Bu kapsamda iki beşinci sınıf, üç altıncı sınıf, iki yedinci sınıf, üç sekizinci sınıf olmak üzere toplam 10 matematik ders kitabı incelenmiştir. Ders kitaplarında yer alan çözümlü örnekler; ilişkilendirme, özel durumları düşünme ve genelleme, değişmezleri araştırma ile keşfetme ve yansıtma alıșkanlıklarının kullanımı bağlamında doküman analizine tabi tutulmuştur. Çalışmanın sonucunda beşinci, altıncı ve yedinci sınıflarda yer alan çözümlü örneklerde en çok ilişkilendirme ile keşfetme ve yansıtma alışkanlıkları kullanılırken sekizinci sınıfta yer alan örneklerde bu alışkanlıkların yanında değişmezleri araştırma alışkanlığına da yer verildiği görülmüş̧ür. Ayrıca her sınıf düzeyinde bilgisayar yazılımına dayalı örnekler olmasına rağmen, bu tür örneklerin daha çok geometrik düşünme alışkanlığına hitap etmesi bağlamında en iyi sekizinci sınıfta kullanıldığı sonucuna ulaşılmıştır. Elde edilen sonuçlardan hareketle bazı önerilerde bulunulmuştur.
\end{abstract}

Anahtar Kelimeler: Geometrik düşünme alışkanlığı, matematik ders kitabı, çözümlü örnekler

Türkçe sürüm için tıklayınız

\section{Introduction}

The main purpose of teaching mathematics and geometry lessons is to provide students with skills such as reasoning with relationship, problem-solving, and critical thinking, which are among the basic 21 st-century skills (Đokić, 2018; Ministry of National Education [MoNE], 2018). Above all, gaining these skills is possible by preparing an effective learning-teaching environment for students. The textbooks used in schools are the most effective material in providing equal education to everyone in learning environments. They are one of the most frequently used materials in educational activities, supported by educational programs and offering equal learning opportunities for everyone (Akdeniz, 2004; Oikonomidis, 2020; Yılmaz, Seçken, \& Morgil, 1998). Therefore, many features such as the ability of the textbooks to address all age levels, to support the acquisitions in the curriculum, to comply with the spelling rules, to be suitable for the language of the student, to serve the purpose of measurement and evaluation, and the quality of the design should be evaluated and they should be prepared separately. The quality and quantity of the selected textbooks change from time to time in line with the curriculum. The need to measure these changing quantities has led many researchers to examine textbooks (Alkan \& Güven, 2018; Altun, Arslan \& Yazgan, 2004; Bingölbali \& Bingölbali, 2020; Bütüner, 2020; Fan, 2013; Herbel-Eisenmann, 2007; Kılıç and Seven, 2002; Kılıçoğlu, 2020; Özkaya \& Duru, 2020; Üredi \& Ulum, 2020; Yaşar, 2005). Some of the studies mentioned above focused on examining measurement and evaluation, design, and scientific content features of the textbooks, and some focused on teachers and students' views on the textbooks (Çelik, Cetinkaya, \& Aydoğan-Yenmez, 2020; Korkmaz, Tutak, \& İlhan, 2020). Apart from these, another important issue to be focused on is thought to be "how and in which direction problem-solving skills in mathematics textbooks work." Problem-solving skills are at the center of the mathematics curriculum prepared in

Corresponding Author: Buket Özüm Bülbül iD_email: cbuketozum@gmail.com

Citation Information: Erşen, Z. B., Bülbül, B. Ö. \& Güler, M. (2021). Analysis of solved examples in mathematics textbooks regarding the use of geometric habits of mind. Turkish Journal of Computer and Mathematics Education, 12(1), $349-377$. http://doi.org/10.16949/turkbilmat.850882 
recent years; this has led to the preparation of mathematics textbooks in that direction (MoNE, 2018; National Council of Teachers of Mathematics, 2000).

When it comes to problem-solving skills, different thinking processes, learning approaches, and habits of mind come to mind. Problem solving is the process of dealing with the problems faced by individuals. In this context, teaching based on problem solving helps students learn mathematics in a conceptual dimension (Schoenfeld, 1992). In the problem solving phase of individuals, the concept of thinking habits emerges (Costa \& Kallick, 2009). Habits of mind are the problem-solving approaches that individuals adopt when faced with a difficult problem (Costa \& Kallick, 2009; Goldenberg, 1996). As can be understood from its definition, the problem-solving and habits of mind are intertwined. Therefore, studies show a positive relationship between individuals' habits of mind and problem-solving success (Bülbül \& Güven, 2019; Bülbül \& Güven, 2020, Bülbül \& Güler, 2021; Driscoll et al., 2007; Driscoll et al., 2008; Erşen, 2018; Gordon, 2011; Marshall, 2004). Different habits of mind have been defined in the literature. In this study, polygons and measurement of area units in mathematics textbooks will be examined; therefore, geometric habits of mind (GHoM) are addressed as the theoretical structure.

\subsection{Geometric Habits of Mind}

Habits of minds are thinking methods that come into play when the solution to a problem is unknown, and they guide the individual in the solution process (Costa \& Kallick, 2009). Lim and Selden (2009) divided the habits of mind into two, general and domain-specific habits of mind. General habits of mind include the approaches to solve the problems that individuals face, such as seeking relationship, gaining experience, and reaching a result by doing experiments. Domain-specific habits of mind involve a discipline such as geometry, mathematics, probability, algebra, analytic and scientific thinking. In this study, the beliefs about GHoM are taken as the basis and mentioned more.

In general, GHoM are in the form of reaching the correct result by doing experiments, exploration and reflection, thinking extreme situations, investing of invariants, reasoning with relationship, thinking special cases, and making generalizations (Bülbül, 2016; Cuoco, Goldenberg, \& Mark, 1996; Driscoll et al., 2008; Goldenberg, 1996). Regarding the use of each habit, GHoM and problem-solving are intertwined. In other words, when students encounter a problem, GHoM affect their solving method. In this case, GHoM allow solving the problem when individuals do not know how to solve it. Driscoll, Wing DiMatteo, Nikula, \& Egan (2007) established the framework of GHoM by applying it to students from fifth to tenth grades. This study is carried out based on the GHoM model established by Driscoll et al. (2007) (see Table 1).

Table 1. Geometric Habits of Mind and Indicators

\begin{tabular}{|c|c|}
\hline $\begin{array}{l}\text { Geometric Habits } \\
\text { of Mind }\end{array}$ & Indicators \\
\hline $\begin{array}{l}\text { Reasoning with } \\
\text { Relationship }\end{array}$ & $\begin{array}{l}\text { It involves looking for relationship between geometric shapes and deciding how they can help } \\
\text { understand the problem or facilitate problem-solving. An individual who has the habit of reasoning } \\
\text { with relationship seeks answers to the following questions in problem-solving: } \\
\text { - What are the similar/different aspects of geometric shapes? } \\
\text { - What are the other shapes that fit the description? } \\
\text { - What if we consider this relationship in different dimensions ( } 2 \text { dimensions-3 dimensions)? }\end{array}$ \\
\hline $\begin{array}{l}\text { Generalizing } \\
\text { Geometric Ideas }\end{array}$ & $\begin{array}{l}\text { It is intended to describe and understand the "always" and the "every" related to geometric phenomena. } \\
\text { An individual who has the habit of generalizing geometric ideas seeks answers to the following } \\
\text { questions in problem-solving: } \\
\text { - Is a special case always valid under all circumstances? } \\
\text { - Can I find other examples suitable for this given particular case? } \\
\text { - Do identified features and generalized expressions work in different dimensions? }\end{array}$ \\
\hline $\begin{array}{l}\text { Investing of } \\
\text { Invariants }\end{array}$ & $\begin{array}{l}\text { It involves analyzing the properties of a geometric shape that changes or stays the same after a } \\
\text { transformation (such as reflection, translation, rotation, splitting, enlarging the shape, or controlled } \\
\text { deformation). An individual who has the habit of investing of invariants seeks answers to the following } \\
\text { questions in problem-solving: } \\
\text { - What are the properties that change and stay as it is when I apply these transformations? } \\
\text { - Why have they changed? } \\
\text { - How can I use invariant properties in problem-solving? }\end{array}$ \\
\hline $\begin{array}{l}\text { Exploration and } \\
\text { Reflection }\end{array}$ & $\begin{array}{l}\text { Individuals with the habit of exploration and reflection can make additional drawings, play with the } \\
\text { shape, or make discoveries on the shape through guessing or intuition. They can check the accuracy of } \\
\text { the problem-solving methods they use. An individual with the habit of exploration and reflection looks } \\
\text { for answers to the following questions in problem-solving: } \\
\text { - What methods can I use to solve the problem? } \\
\text { - How can I use the additional drawings I made on the given geometric shapes in the problem- } \\
\text { - Holving process? }\end{array}$ \\
\hline
\end{tabular}


As stated in Table 1, Driscoll et al. (2007) divided GHoM into four: reasoning with relationship, generalizing geometric ideas, investing of invariants, and exploration and reflection. The habit of reasoning with relationship mostly involves comparing and classifying geometric objects and determining the similarities and differences between geometric shapes. The habit of generalizing geometric ideas shows a special case's validity and makes a generalization using this validity. Investing of invariants habit involves using the properties that do not change after the transformations made to given geometric shapes in solving problems. Finally, the habit of exploration and reflection involves using different solution strategies, making additional drawings on geometric shapes, and checking the validity of all solutions.

GHoM can positively or negatively affect students' achievement in mathematics and problem-solving. Considering that textbooks are the most used materials when teaching mathematics lessons, the need for examining the problems in textbooks arises. There is no hierarchical order or cycle among the GHoM described above (Driscoll et al., 2007). In other words, while a student uses the habit of reasoning with relationship in solving a problem, another student can solve the same problem using both the habits of exploration and reflection and reasoning with relationship. We cannot decide which GHoM to be used by looking at a problem. The solutions to the problem should be examined in detail to make a decision. The solved examples in the mathematics textbooks should be examined because GHoM can change according to the solution. This study examines the solved examples used in the subjects of polygons and measurement of area in mathematics textbooks approved to be taught as of the 2020-2021 academic year, within the scope of GHoM.

\section{Method}

In this study, the mathematics textbooks were repeatedly examined and interpreted in terms of GHoM; thus, the document analysis method was employed. Document analysis is a method used to carefully and systematically analyze textbooks or written studies (Wach, 2013).

\subsection{Data Collection and Analysis}

In this study, all middle school mathematics textbooks approved to be instructed by the Ministry of National Education for use in 2020-2021 academic year were examined. In this context, the publishing houses of examined mathematics textbooks are the followings: MoNE and Tuna for the fifth Grade, MoNE 1, MoNE 2 and Öğ̈̈n for the sixth Grade, Ekoyay and MoNE for the seventh grade, and Kök-e, MoNE 1, and MoNE 2 for the eighth grade. Cover pages of these books are presented in Appendix 1. The solved problems examined within the scope of GHoM belong to the following units: the triangles and quadrilaterals for the fifth grade, the measurement of area for the sixth grade, the polygons for the seventh grade, and the triangles for the eighth grade (see Table 2). The reason for choosing these units is that a) These units are the longest and most comprehensive units, and b) There are different sections and units in geometry and measurement areas at each grade level, but these are the most comprehensive units that can contain all of them at the same time.

Table 2. Examined Mathematics Textbooks and the Units

\begin{tabular}{ccc}
\hline Grade & Publishing Houses & Units \\
\hline \multirow{2}{*}{$5^{\text {th }}$ grade } & MoNE & Triangles and Quadrilaterals \\
\cline { 2 - 3 } & TUNA & Triangles and Quadrilaterals \\
\cline { 2 - 3 } $6^{\text {th }}$ grade & MoNE 1 & Measurement of Area \\
\cline { 2 - 3 } & MoNE 2 & Measurement of Area \\
\cline { 2 - 3 } $7^{\text {th }}$ grade & ÖG̈̈ & Measurement of Area \\
\cline { 2 - 3 } & MoNE & Polygons \\
\hline \multirow{2}{*}{8 th grade } & EKOYAY & Polygons \\
\cline { 2 - 3 } & MoNE 1 & Triangles \\
\cline { 2 - 3 } & MoNE 2 & Triangles \\
\hline
\end{tabular}

As seen in Table 2, the solved examples in a total of 10 mathematics textbooks, including two fifth grade, three sixth grade, two seventh grade, and three eighth grade, were analyzed. The solved samples were examined separately by each researcher and coded separately by the two researchers considering the GHoM and indicators presented in Table 1 developed by Driccoll et al. (2007). As a result of the reliability analysis obtained by comparing the given codes, the reliability coefficient was 0.82 . Discussion was conducted for the differentiating codes until consensus was reached by the researchers. After creating common codes, the data are presented in tables. Figure 1 includes an example of a solved problem and its analysis regarding the use of GHoM. 
Example 7

In the trapezoid $\mathrm{ABCD},|\mathrm{AB}|=8 \mathrm{~cm},|\mathrm{DC}|=14 \mathrm{~cm}$ and $A(A B D)=24 \mathrm{~cm}^{2}$ are given. Let's find out the area of $(A B C D)$.

Solution

Draw $[\mathrm{DH}]$ from point $\mathrm{D}$, where $[\mathrm{AB}] \perp[\mathrm{DH}]$.

Since the ABD triangle is obtuse-angled, the height of the side $[\mathrm{AB}]$ is [DH]. $\mathrm{DH}$ is alsc the height of the ABCD trapezoid.

$$
\begin{aligned}
\mathrm{A}(\widehat{\mathrm{ABD}}) & =\frac{|\mathrm{AB}| \cdot|\mathrm{DH}|}{2} \\
24 & =\frac{8 \cdot|\mathrm{DH}|}{2} \\
48 & =8 \cdot|\mathrm{DH}|,|\mathrm{DH}|=6 \\
\mathrm{~A}(\mathrm{ABCD}) & =\frac{(|\mathrm{AB}|+|\mathrm{DC}|) \cdot|\mathrm{DH}|}{2}=\frac{(8+14) \cdot 6}{2}=22 \cdot 3 \\
\mathrm{~A}(\mathrm{ABCD}) & =66 \mathrm{~cm}^{2}
\end{aligned}
$$

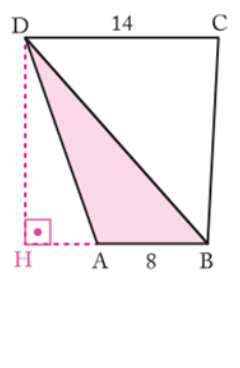

Figure 1. A solved example from the seventh-grade book of the Ekoyay publication house

In the example in Figure 1, the area of the ABD triangle and the length of certain sides are given, and the trapezoid area is asked. In the solution, the trapezoid is transformed into a quadrilateral by drawing a perpendicular line from point D. Since an additional drawing is made on the figure, the habit of exploration and reflection is used. Regarding the continuation of the solution, reasoning with relationship is made between the sides and height to find the trapezoid area. Therefore, at this stage, the habit of reasoning with relationship is used in the solution. Consequently, this example was coded as Reasoning with relationship + Exploration and reflection.

\section{Findings}

In this study, solved examples in mathematics textbooks were analyzed according to the GHoM. In this context, the distribution of the number of solved samples according to GHoM and publishing houses was examined (see Table 2).

Table 2. Overall Analysis of Solved Examples in Mathematics Textbooks

\begin{tabular}{ccccc}
\hline \multirow{2}{*}{$5^{\text {th }}$ grade } & Publishing House & Unit Name & $\begin{array}{c}\text { Number of } \\
\text { Solved Example }\end{array}$ & Number of GHoM Used \\
\cline { 2 - 5 } & MoNE & Triangles and Quadrilaterals & 22 & 34 \\
\hline \multirow{2}{*}{$6^{\text {th }}$ grade } & MUNA & Triangles and Quadrilaterals & 20 & 26 \\
\cline { 2 - 5 } & MoNE 1 & Measurement of Area & 21 & 34 \\
\cline { 2 - 5 } & ÖĞ̈̈N & Measurement of Area & 23 & 39 \\
\hline \multirow{2}{*}{$7^{\text {th }}$ grade } & MoNE & Measurement of Area & 32 & 77 \\
\cline { 2 - 5 } & EKOYAY & Polygons & 49 & 87 \\
\hline \multirow{2}{*}{ 8th grade } & MoNE 1 & Polygons & 70 & 84 \\
\cline { 2 - 5 } & MoNE 2 & Triangles & 48 & 41 \\
\cline { 2 - 5 } & KÖK-E & Triangles & 24 & 51 \\
\hline
\end{tabular}

Regarding Table 2, the maximum number of solved examples is given in the seventh grade. In the seventh grade textbook, Ekoyay publishing house gave 70 solved examples for the unit "Polygons," and MoNE publishing house gave 49 solved examples for the same unit. The grades with the least number of solved examples are the fifth and sixth grades. MoNE publishing house gave 22 solved examples for the "Triangles and Quadrilaterals" unit in the fifth grade, while Tuna publishing house gave 20 solved examples for the same unit of the same grade. Similarly, MoNE1, MoNE2, and Öğün publishing houses respectively gave 21, 23, and 32 solved examples for the "Measurement of Area" unit of the sixth grade. Another remarkable finding in Table 2 is 
that the number of used GHoM is higher than the number of solved examples. There are 22 solved examples in the fifth-grade MoNE publishing house textbook, but 34 GHoM are used; besides, 26 GHoM are used in the 20 solved examples of the Tuna publishing house textbook. Similarly, in the sixth grade, 34 GHoM are used in the 21 solved examples of MoNE 1 publishing house textbook, 39 GHoM are used in the 23 solved examples of MoNE 2 publishing house textbook, and $50 \mathrm{GHoM}$ are used in the 32 solved examples of Öğ̈n publishing house textbook. In the seventh grade, $87 \mathrm{GHoM}$ are used in the 70 solved examples of Ekoyay publishing house textbook, and 77 GHoM are used in the 49 solved examples of MoNE publishing house textbook. Finally, in the eighth grade, $51 \mathrm{GHoM}$ are used in the 28 solved examples of the Kök-e publishing house textbook, $41 \mathrm{GHoM}$ are used in the 24 solved examples of MoNE 2 publishing house textbook, and 84 GHoM are used in the 48 solved examples of MoNE 1publishing house textbook

\subsection{Analysis of Solved Examples in Fifth Grade Mathematics Textbooks}

The analysis of solved examples in fifth-grade mathematics textbooks regarding the use of GHoM is given in Table 3.

Table 3. Analysis of Solved Examples in Fifth Grade Mathematics Textbooks

\begin{tabular}{|c|c|c|c|c|c|c|c|c|c|c|c|}
\hline & & \multicolumn{2}{|c|}{$\begin{array}{l}\text { Reasoning with } \\
\text { relationship }\end{array}$} & \multicolumn{2}{|c|}{$\begin{array}{l}\text { Generalizing } \\
\text { geometric ideas }\end{array}$} & \multicolumn{2}{|c|}{$\begin{array}{l}\text { Investing of } \\
\text { invariants }\end{array}$} & \multicolumn{2}{|c|}{$\begin{array}{l}\text { Exploration and } \\
\text { reflection }\end{array}$} & \multicolumn{2}{|c|}{ No habit } \\
\hline & & $\mathrm{f}$ & $\%$ & $\mathrm{f}$ & $\%$ & $\mathrm{f}$ & $\%$ & f & $\%$ & $\mathrm{f}$ & $\%$ \\
\hline \multirow{2}{*}{$5^{\text {th }}$ grade } & MoNE & 21 & 61.76 & 2 & 5.88 & 2 & 5.88 & 8 & 23.53 & 1 & 2.95 \\
\hline & Tuna & 20 & 76.92 & - & - & - & - & 6 & 23.08 & - & - \\
\hline
\end{tabular}

Table 3 shows that $61.76 \%$ of the solved examples in the MoNE textbook use reasoning with relationship, $23.53 \%$ exploration and reflection, $5.88 \%$ investing of invariants, and 5.88\% generalizing geometric ideas habits. Of the solved examples in Tuna publishing house, $76.92 \%$ use reasoning with relationship, and $23.07 \%$ use exploration and reflection habits. The habits of investing of invariants and generalizing geometric ideas are not encountered in any of the solved examples in the Tuna publishing house textbook. In both publishers, reasoning with relationship is used the most, followed by the habit of exploration and reflection. The habit of reasoning with relationship used in solved examples is generally in the form of establishing relationship between areasperimeter-side lengths of given geometric shapes, comparing interior angles of polygons, or establishing relationship between quadrilaterals (see Figure 2).

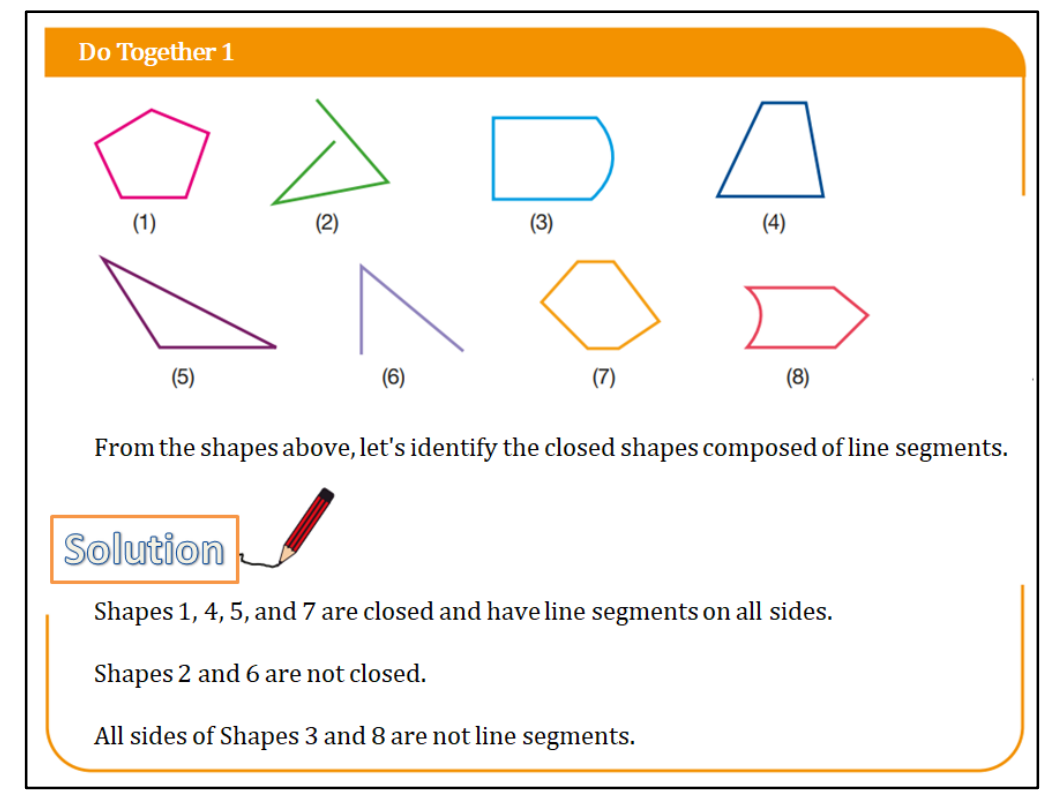

Figure 2. A solved example from the fifth-grade book of the MoNE publication house

In Figure 2, there is a solved example in the form of "From the above figures identify the closed shapes formed by line segments." In the solution, closed geometric shapes are associated with their sides. Therefore, the habit of reasoning with relationship is used in the solution. The habit of reasoning with relationship is used alone in some solved examples, whereas it is used together with the habit of exploration and reflection in some others. A similar example is illustrated in Figure 3. 


\section{EXAMPLE - 1}

Let's draw a right triangle on the dotted paper.

\section{SOLUTION}

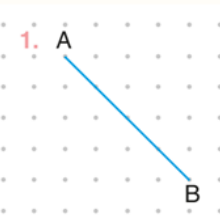

Draw an $[\mathrm{AB}]$ of the desired length on the dotted paper, to form a side of a right triangle.

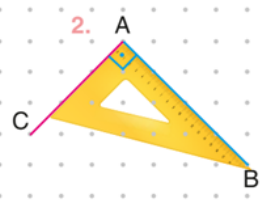

Draw $[\mathrm{AC}]$ perpendicular to $[\mathrm{AB}]$ at point $\mathrm{A}$, using the square's vertical corner.

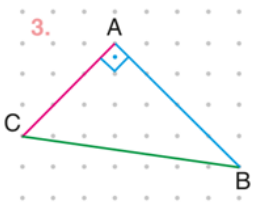

Draw $[\mathrm{BC}]$ by connecting points $\mathrm{B}$ and $\mathrm{C}$. In the resulting $\mathrm{CAB}$ triangle, $\hat{A}$ is the right angle, $\hat{B}$ and $\hat{C}$ are acute angles.

Figure 3. A solved example from the fifth-grade book of the Tuna publication house

Regarding the solved example in Figure 3, a right triangle is drawn with a ruler's help. While doing this drawing, the features of dotted paper and ruler are employed. The habit of reasoning with relationship is used by associating the distance between the dots and the ruler's right angle with the sides of the triangle and the habit of exploration and reflection by making an additional drawing. In some solved examples of fifth-grade mathematics books, reasoning with relationship habit is used together with other GHoM (see Figure 4).

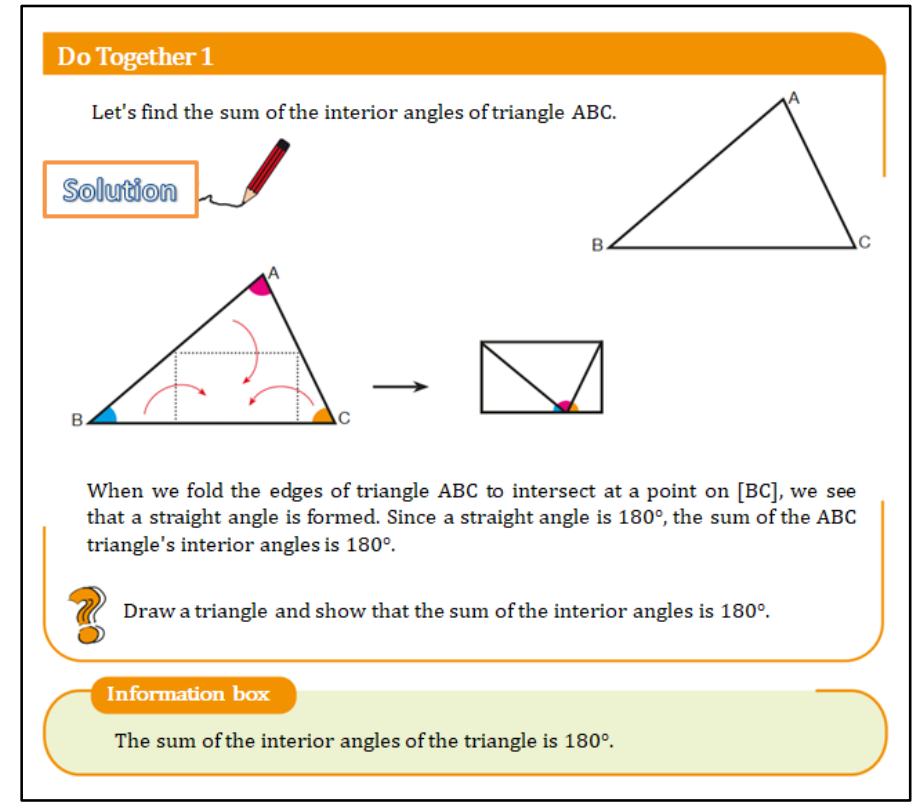

Figure 4. A solved example from the fifth-grade book of the MoNE publication house

Regarding the solved example in Figure 4, the triangle is folded, and the folded parts are intersected on the rectangle's bottom side. Actually, a change was made in the appearance of the geometric shape by folding. The GHoM used in this example include investing of invariants by manipulating the shape and using invariant features in the solution; reasoning with relationship by setting a relationship with the angles of the folded triangles; exploration and reflection by adding a new shape in the solution process; and generalizing geometric ideas by creating a general rule using a special case (The sum of the interior angles of the triangles is $180^{\circ}$ ). Therefore, as seen in this example, all GHoM can be used in a solved example. On the other hand, no GHoM was encountered in a solved example of the fifth-grade mathematics textbook (see Figure 5). 


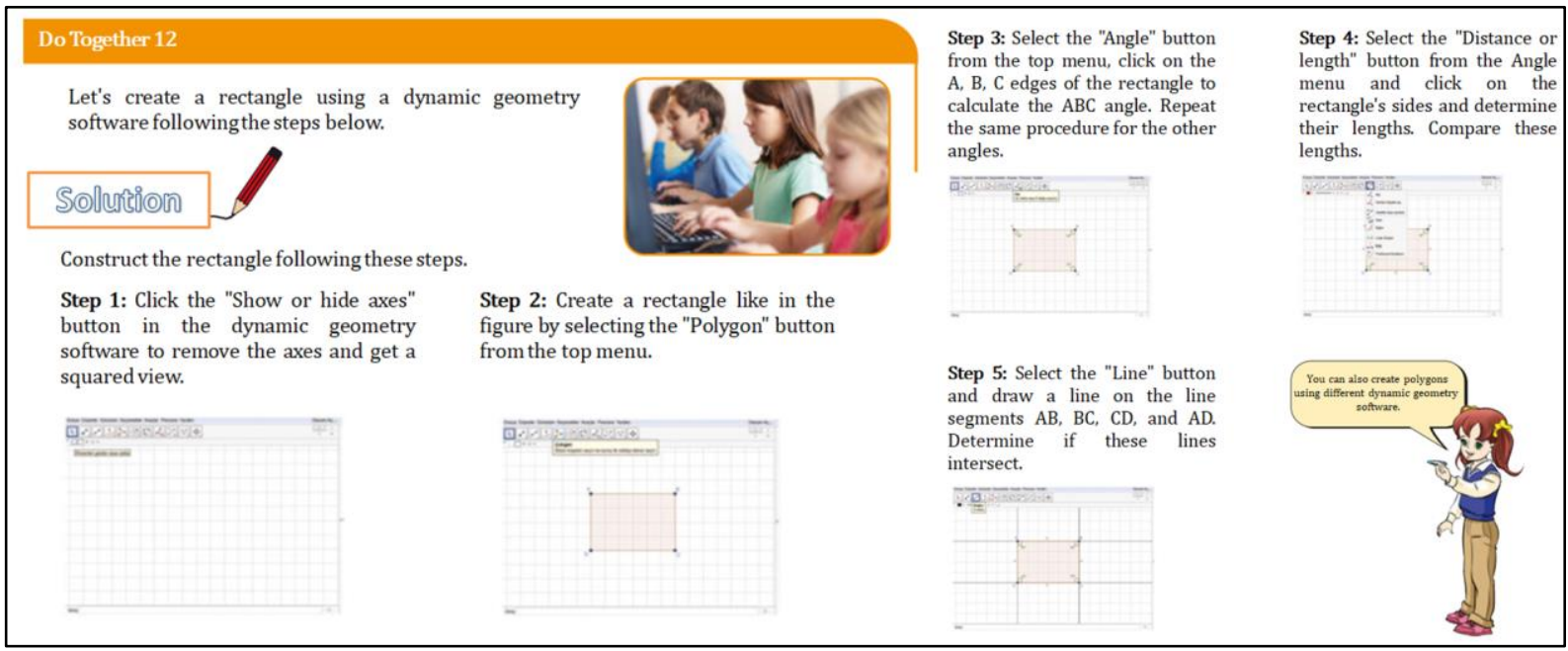

Figure 5. A solved example from the fifth-grade book of the MoNE publication house

In the solved example in Figure 5, students are asked to create a rectangle using dynamic geometry software. There is no information about this software in any part of the book. Therefore, it is not known whether fifthgrade students can use this software or not. Besides, all steps to be followed in the geometry software are explained one by one, and the student is not lead to use any habits of mind. As a result of all these, the example above was coded as "no habit is observed" by the researchers.

\subsection{Analysis of Solved Examples in Sixth Grade Mathematics Textbooks}

The analysis of solved examples in sixth-grade mathematics textbooks regarding the use of GHoM is given in Table 4.

Table 4. Analysis of Solved Examples in Sixth Grade Mathematics Textbooks

\begin{tabular}{|c|c|c|c|c|c|c|c|c|c|c|c|}
\hline & & \multicolumn{2}{|c|}{$\begin{array}{l}\text { Reasoning with } \\
\text { relationship }\end{array}$} & \multicolumn{2}{|c|}{$\begin{array}{l}\text { Generalizing } \\
\text { geometric ideas }\end{array}$} & \multicolumn{2}{|c|}{$\begin{array}{l}\text { Investing of } \\
\text { invariants }\end{array}$} & \multicolumn{2}{|c|}{$\begin{array}{l}\text { Exploration and } \\
\text { reflection }\end{array}$} & \multicolumn{2}{|c|}{ No habit } \\
\hline & & $\mathrm{f}$ & $\%$ & $\mathrm{f}$ & $\%$ & $\mathrm{f}$ & $\%$ & $\mathrm{f}$ & $\%$ & $\mathrm{f}$ & $\%$ \\
\hline \multirow{3}{*}{ 6. sinif } & MoNE1 & 20 & 58.82 & - & - & 2 & 5.88 & 12 & 35.3 & - & - \\
\hline & MoNE 2 & 23 & 58.99 & 1 & 2.56 & 3 & 7.69 & 12 & 30.76 & - & - \\
\hline & ÖĞÜN & 29 & 58 & 3 & 6 & 3 & 6 & 15 & 30 & - & - \\
\hline
\end{tabular}

Table 4 shows that $58.82 \%$ of the solved examples in the MoNE1 textbook use reasoning with relationship, $35.29 \%$ exploration and reflection, 5.88\% investing of invariants. Regarding the solved examples in the MONE2 publishing house textbook, 58.97\% use reasoning with relationship, 30.76\% use exploration and reflection, $7.69 \%$ use investing of invariants, and $2.56 \%$ use generalizing geometric ideas habits. Finally, in the solved examples of Öğ̈̈n publishing house textbook, 58\% use reasoning with relationship, 30\% use exploration and reflection, $6 \%$ use investing of invariants, and another $6 \%$ use generalizing geometric ideas habits. There is no solved example without any GHoM in sixth-grade mathematics textbooks. The solved examples in the books of the sixth grade MoNE1 and MoNE2 publication houses are generally associated with daily life (see Figure 6). 


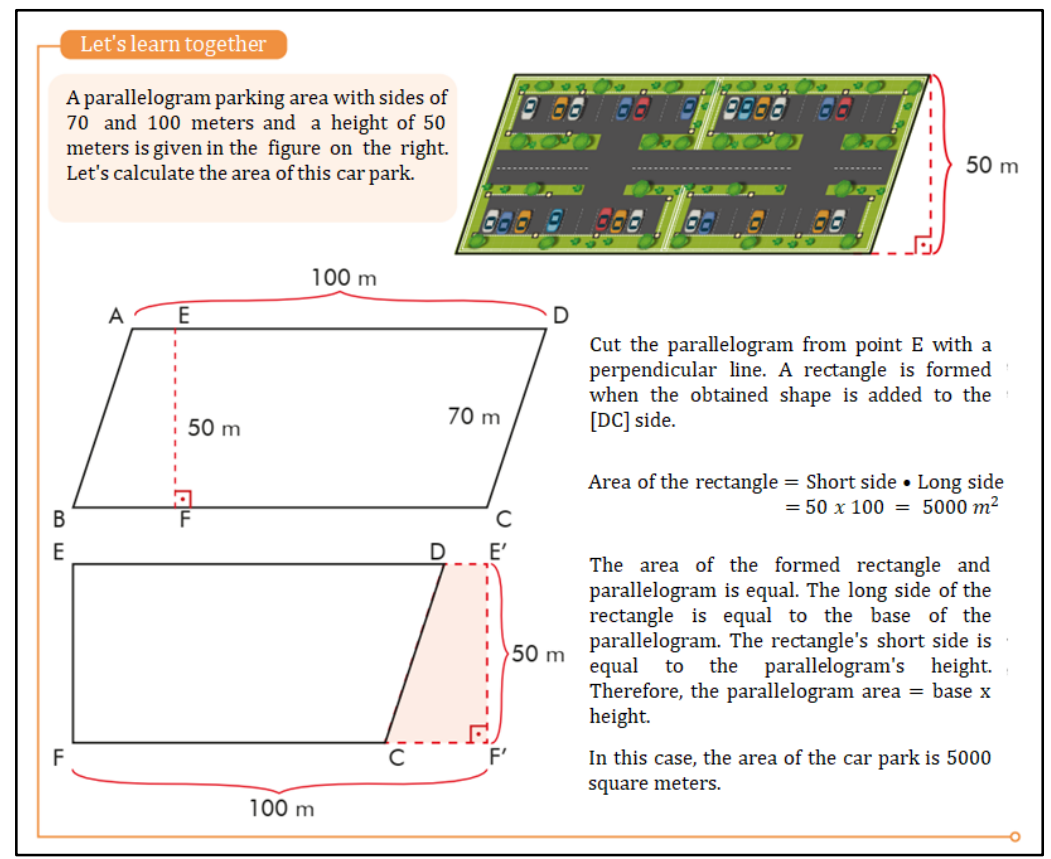

Figure 6. A solved example from the sixth-grade book of the MoNE publication house

The example given in Figure 6 from the sixth grade textbook of MoNE1 publishing house is related to daily life. While solving the example, a trapezoid shape was cut from one side of the given parallelogram and added to the other side. The answer was found after obtaining the rectangular shape with this method. Investing of invariants and exploration and reflection habits are used by cutting the trapezoid shape and adding it to the other side. The habit of reasoning with relationship was also used by establishing a relationship between the length of the sides and the area. Accordingly, the habits of exploration and reflection, reasoning with relationship, and investing of invariants are used in the solution of the example in Figure 6.

\subsection{Analysis of Solved Examples in Seventh Grade Mathematics Textbooks}

The analysis of solved examples in seventh-grade mathematics textbooks regarding the use of GHoM is given in Table 5.

Table 5. Analysis of Solved Examples in Seventh Grade Mathematics Textbooks

\begin{tabular}{|c|c|c|c|c|c|c|c|c|c|c|c|}
\hline & & \multicolumn{2}{|c|}{$\begin{array}{l}\text { Reasoning with } \\
\text { relationship }\end{array}$} & \multicolumn{2}{|c|}{$\begin{array}{c}\text { Generalizing } \\
\text { geometric ideas }\end{array}$} & \multicolumn{2}{|c|}{$\begin{array}{l}\text { Investing of } \\
\text { invariants }\end{array}$} & \multicolumn{2}{|c|}{$\begin{array}{l}\text { Exploration and } \\
\text { reflection }\end{array}$} & \multicolumn{2}{|c|}{ No habit } \\
\hline & & $\mathrm{f}$ & $\%$ & $\mathrm{f}$ & $\%$ & $\mathrm{f}$ & $\%$ & $\mathrm{f}$ & $\%$ & $\mathrm{f}$ & $\%$ \\
\hline \multirow{2}{*}{ 7. sinif } & MoNE & 44 & 57.16 & 6 & 7.79 & 3 & 3.89 & 19 & 24.67 & 5 & 6.49 \\
\hline & EKOYAY & 59 & 67.83 & 4 & 4.59 & - & - & 13 & 14.94 & 11 & 12.64 \\
\hline
\end{tabular}

Table 5 shows that in the Ekoyay textbook, $67.81 \%$ of the solved examples use the habit of reasoning with relationship, $14.94 \%$ exploration and reflection, and $4.59 \%$ generalizing geometric ideas. $12.64 \%$, on the other hand, do not use any GHoM. Regarding the solved examples in the MONE publishing house textbook, 57.14\% use the habit of reasoning with relationship, $24.67 \%$ use exploration and reflection, $7.79 \%$ use generalizing geometric ideas, and $3.89 \%$ investing of invariants. $6.49 \%$ of the solved examples in the MoNE publishing house textbook do not use any GHoM. Reasoning with relationship and exploration and reflection habits are the most used habits in the seventh-grade textbook's solved examples. Reasoning with relationship and exploration and reflection habits are used together in the seventh grade's solved examples. Figure 7 contains such an example. 


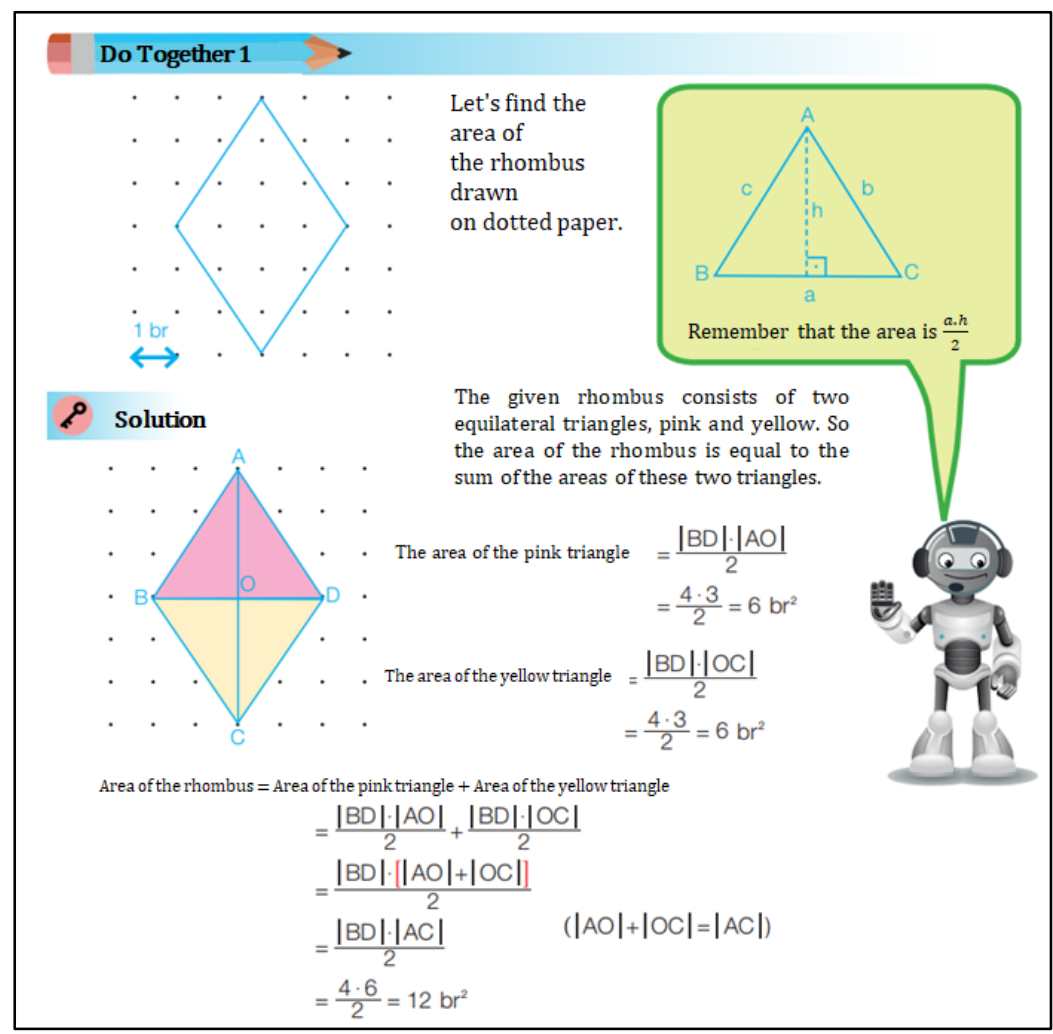

Figure 7. A solved example from the seventh-grade book of the MoNE publication house

In the solved example of MoNE publishing house in Figure 7, the rhombus' diagonals are drawn. The triangles' areas are associated with the rhombus area, and the correct result is achieved. The habit of exploration and reflection is observed since additional drawings are used and reasoning with relationship because the rhombus area is associated with the triangle area. In some cases, the habit of reasoning with relationship is used with exploration and reflection and with generalizing geometric ideas (see Figure 8).

The solved example in Figure 8 involves finding the sum of the outer angles of the polygons. First, the sum of the triangle's outer angles and then the pentagon's are calculated. The habit of exploration and reflection is used because geometric shapes are drawn while measuring the external angles. A general rule has been established for all polygons after showing the solution's validity on the triangles and rectangles. At this stage, the habit of generalizing geometric ideas is used.

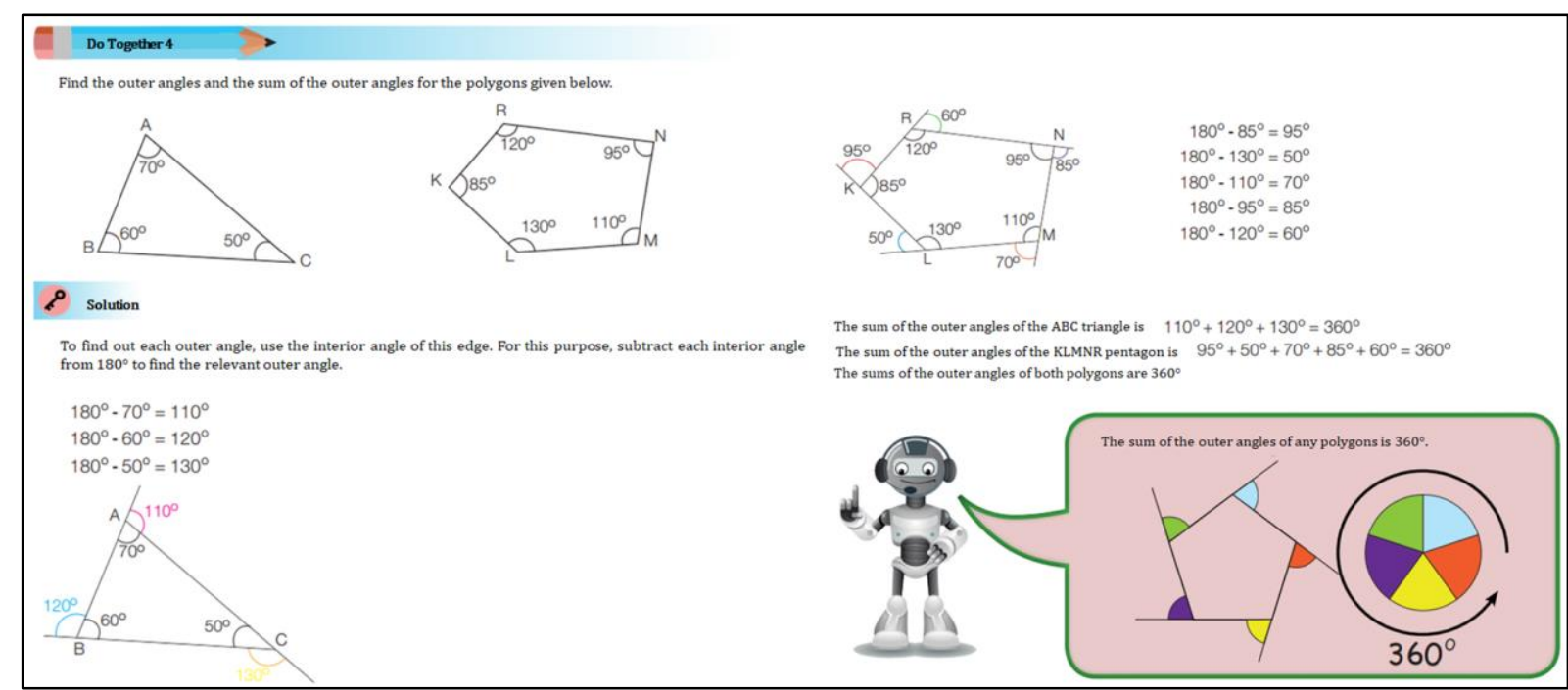

Figure 8. A solved example from the seventh-grade book of the MoNE publication house

Some solved examples in seventh-grade mathematics textbooks are intended to be used directly after the mathematical formulas are given (see Figure 9). Since such examples do not require any habits of mind, they were coded as "no habit" by the researchers. 


$$
\begin{aligned}
& \text { In the figure on the right, a circle with center } 0 \text {, having a radius of } \\
& 14 \mathrm{~cm} \text {, is given. Find the area of the segment of the circle formed } \\
& \text { by the central angle } \alpha=90^{\circ} \text { (take } \pi=3 \text { ). } \\
& \text { Solution } \\
& \mathrm{A}(\mathrm{KOL})=\pi \mathrm{r}^{2} \cdot \frac{\alpha}{360^{\circ}} \\
& =3 \cdot 14^{2} \cdot \frac{90^{\circ}}{\frac{360^{\circ}}{4}} \\
& =\frac{3 \cdot 196}{4} \\
& =\frac{3 \cdot 49}{1} \\
& \mathrm{~A}(\mathrm{KOL})=147 \mathrm{~cm}^{2}
\end{aligned}
$$

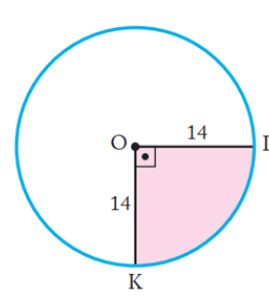

\begin{tabular}{|c|c|c|c|c|c|c|c|c|c|c|c|}
\hline & & \multicolumn{2}{|c|}{$\begin{array}{l}\text { Reasoning with } \\
\text { relationship }\end{array}$} & \multicolumn{2}{|c|}{$\begin{array}{c}\text { Generalizing } \\
\text { geometric ideas }\end{array}$} & \multicolumn{2}{|c|}{$\begin{array}{c}\text { Investing of } \\
\text { invariants }\end{array}$} & \multicolumn{2}{|c|}{$\begin{array}{c}\text { Exploration and } \\
\text { reflection }\end{array}$} & \multicolumn{2}{|c|}{ No habit } \\
\hline & & $\mathrm{f}$ & $\%$ & $\mathrm{f}$ & $\%$ & $\mathrm{f}$ & $\%$ & $\mathrm{f}$ & $\%$ & $\mathrm{f}$ & $\%$ \\
\hline \multirow{3}{*}{ 8. sinif } & MoNE 1 & 46 & 54.77 & 6 & 7.14 & 7 & 8.33 & 24 & 28.57 & 1 & 1.19 \\
\hline & MoNE 2 & 23 & 56.12 & 6 & 14.63 & 2 & 4.87 & 9 & 21.95 & 1 & 2.43 \\
\hline & KÖK-E & 27 & 52.95 & 3 & 5.88 & 4 & 7.84 & 17 & 33.33 & - & - \\
\hline
\end{tabular}

Figure 9. A solved example from the seventh-grade book of the Ekoyay publication house

In Figure 9, there is a solved example directly finding the area of the sector. Such solved examples are frequently encountered, especially in Ekoyay publishing house. Since mathematical formulas are directly used when solving such examples, no geometric habit is used in the solution process.

\subsection{Analysis of Solved Examples in Eighth Grade Mathematics Textbooks}

The analysis of solved examples in eighth-grade mathematics textbooks regarding the use of GHoM is given in Table 6.

Table 6. Analysis of Solved Examples in Eighth Grade Mathematics Textbooks

Table 6 shows that in the Kök-e publishing house textbook, $52.94 \%$ of the solved examples use the habit of reasoning with relationship, 33.33\% exploration and reflection, $7.84 \%$ investing of invariants, and 5.88\% generalizing geometric ideas. Regarding the solved examples in the MONE2 publishing house textbook, 56.09\% use the habit of reasoning with relationship, $21.95 \%$ use exploration and reflection, $14.63 \%$ use generalizing geometric ideas, and $4.87 \%$ investing of invariants. $2.43 \%$, on the other hand, do not have any GHoM. Finally, in the MoNE 1 publishing house textbook, $54.76 \%$ of the solved examples use the habit of reasoning with relationship, $28.57 \%$ exploration and reflection, $8.33 \%$ investing of invariants, and $7.14 \%$ generalizing geometric ideas. No GHoM is encountered in $1.19 \%$ of the solved examples.

Regarding solved examples in eighth-grade mathematics textbooks, GHoM are sometimes used alone, sometimes with other habits. Figure 10 shows an example in which the habits of reasoning with relationship, exploration and reflection, and generalizing geometric ideas are used together. 


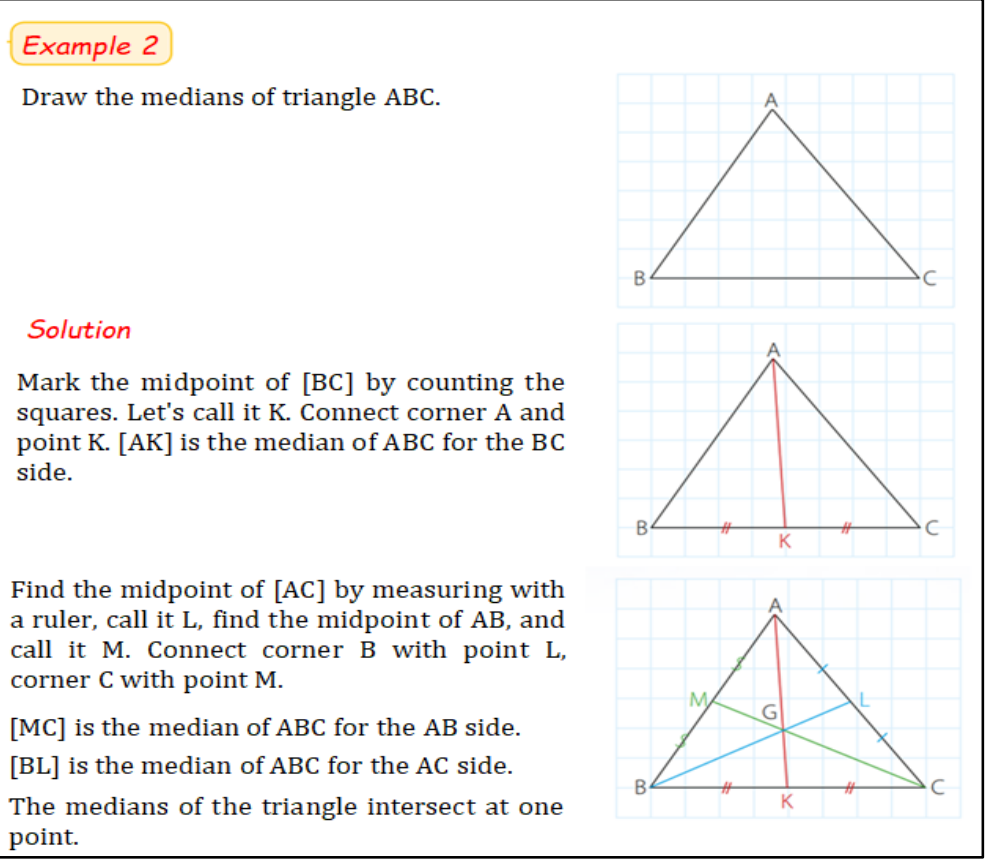

Figure 10. A solved example from the eighth-grade book of the Kök-e publication house

An example involving drawing the medians of a triangle is given in Figure 10. In this example, the medians drawn from corners A, B, and C are shown in the figure. Then, it is underlined that all medians intersect at one point. In this solution, the habit of exploration and reflection is used since additional drawings are made on the figure; the habit of generalizing geometric ideas is used since a general rule is created by using the validity of the special cases, and the habit of reasoning with relationship is used because the edges are associated with the medians. In some solved examples, the habit of reasoning with relationship is used alone (see Figure 11).

Example 2

For the triangles below, find the natural numbers that missing side lengths can take.

a)

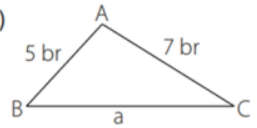

c)

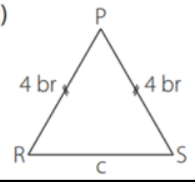

b)

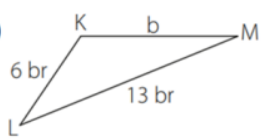

Solution

Missing side lengths must be lower than the sum of the remaining two sides and higher than the absolute value of their difference.

a) Because $7+5=12>\mathrm{a}|7-5|=1<\mathrm{a}$; a must be greater than 2 and smaller than 12. Therefore a can be $3,4,5,6,7,8,9,10$ and 11 natural numbers.

b) Because $13+6=19>$ b $|13-6|=7<$; b can be $8,9,10,11,12,13,14,15,16,17$ and 18 natural numbers.

c) Because $4+4=8>c|4-4|=0<c$; $c$ can be $1,2,3,4,5,6$ and 7 natural numbers.

Figure 11. A solved example from the eighth-grade book of the Kök-e publication house

Three different triangles and some of their side lengths are given in Figure 11. Students are asked to comment on whether these triangles can be drawn by considering these lengths. The solution of the example is based on the assumption that "In order for a triangle to be drawn, ungiven side lengths must be smaller than the sum of the other side lengths and greater than the absolute value of the difference." In this solution, the result is achieved by reasoning with relationship between triangles and side lengths. In this solution process, the habit of reasoning with relationship was used alone.

\section{Discussion, Conclusion and Suggestions}

This study aimed to examine the solved examples used in polygons and measurement of area subjects of mathematics textbooks approved for the 2020-2021 academic year in terms of GHoM. For this purpose, all mathematics textbooks in primary education were analyzed using document analysis. The number of solved examples in the textbooks in descending order is seventh, eighth, sixth, and fifth grades. Providing a higher number of examples is very important for developing GHoM (Driscoll et al., 2007; Driscoll et al., 2008, Cuoco et al., 1996). Therefore, it can be said that solved examples in the seventh and eighth grades play an important role in increasing GHoM and problem-solving achievement. The literature emphasizes that the abundance of examples and problems in mathematics textbooks and their addressing to different solutions positively affect 
students' understanding of the subject (Kwon, Park, \& Park, 2006; Sawada, 1997). As Driscoll et al. (2007) stated, solving many examples helps students use their GHoM in an experienced way.

Therefore, the increase in the number of solved examples in the textbooks will positively affect students' problem-solving processes and help them use their GHoM consciously. However, it does not mean that asking too many questions of the same type positively affects students' habits. As in the definition, GHoM are the approaches of individuals towards the problem's solution when faced with a difficult problem. Asking many nonroutine problems to students will help them activate these habits. For example, there are 70 solved examples about polygons in the seventh-grade textbook of Ekoyay publishing house. However, most of these examples are routine problems for practice. Again, habit is not observed in most of these solved examples. Therefore, asking students many exercise type questions may provide limited benefit in activating GHoM. The point that should be kept in mind here is to include questions that require different habits of mind as much as possible and provide many examples. Including different types of questions concerning different habits of mind'indicators will help develop students' geometric perspectives.

Regarding GHoM, reasoning with relationship is used at the highest level in all grades and by all publishing houses. The habits of reasoning with relationship and exploration and reflection are very important in a geometry problem's solution process. Regarding the indicators of reasoning with relationship and exploration and reflection, they include making an additional drawing in geometric shapes, establishing a relationship between area-side length in a triangle, drawing height in triangles with different angles, and comparing the properties of geometric shapes with each other. In this context, it can be said that developing students' habits of reasoning with relationship and exploration and reflection at the primary education plays an important role in solving the problems encountered in the future. Because the better the students can establish a relationship between the geometric shapes they encounter, the better they will be able to associate the geometric shapes they have learned before with their new learning in solving problems and the better they will be able to produce solutions to the problems they encounter (Cuoco, Goldenberg, \& Mark, 1996; Driscoll et al., 2007; Leikin, 2007; Seago, Jacobs, Driscoll, Nikula, Matassa, \& Callahan, 2013). For this reason, Cuoco, Goldenberg, and Mark (1996) emphasized that one of the most basic mathematical and GHoM that should be present in the curriculum based on habits of mind is reasoning with relationship. "Making an additional drawing that can help solve the problem," which is one of the indicators of exploration and reflection habit, is used in most of the solved examples. The examples involving additional drawing lead students to establish relationship between them and explore geometric shapes' structures. Therefore, additional drawings made for solving the geometry problem will guide students to establish relationship between geometric structures and help the problem-solving process. It should be noted that there are few examples of other indicators of exploration and reflection in most mathematics textbooks. The inclusion of solved examples in which the habit of "developing different solution strategies when the problem cannot be solved," which is an important indicator of exploration and reflection habit, is particularly important to give a new perspective to solve geometry problems.

The habits of reasoning with relationship and exploration and reflection are at the core of many solved examples in mathematics textbooks. As the analysis of solved examples is detailed, the habits of reasoning with relationship and exploration and reflection are usually used in examples involving the use of isometric/dotted/squared paper, as in the examples given by Driscoll et al. (2007). These papers lead to draw a new geometric shape and make reasoning with relationship of the shape and side lengths/area/perimeter. Reasoning with relationship, investing of invariants, and exploration and reflection habits are generally used together in the examples requiring compasses and folding paper. Apart from these, all GHoM are observed to be used together in examples involving finding a general rule or pattern by showing the validity of different cases.

Another significant issue regarding mathematics textbooks is that there are very few examples using the habit of investing of invariants. The examples that require the use of this habit include the activities involving cutting and pasting or folding. The literature shows that dynamic geometry software affects students' analyses of variable/invariant structures in geometry and their dynamic thinking (Cuoco et al., 2010; Kılıç, 2013; Seago, Jacobs, Heck, Nelson, \& Malzahn, 2015). In this context, increasing such activity examples in the textbooks will help develop this habit and benefit from technology in geometry. Again, the examples in the textbooks show that generalizing geometric ideas is rarely used in the fifth grade, and it is used sparingly in other grades. This habit considers all possible cases in an example and adapts a special case to the general.

The review of solved examples in mathematics textbooks according to grade shows that the least solved example is given at the fifth-grade, whereas the most solved example is provided at the seventh and eighthgrades. One of the reasons for this situation may be that seventh and eighth-grade students need to prepare for the high-school entrance exam. It can be said that students' problem-solving skills improve as their development levels increase. Besides, in all grades, there are examples in which computer software is used, as stated in MoNE (2018). However, such examples may prevent fifth-grade students from finding effective solutions. In other words, telling the student step by step what to do and failing to explain the software can distract students from using their GHoM. On the contrary, the computer-aided examples in the textbooks should help students 
concretize abstract concepts as the development of abstraction skills also affects the development of students' problem-solving skills (Kılıçoğlu, 2020). Since the development of problem-solving skills positively affects the use of GHoM (Bülbül \& Güven, 2019; Bülbül \& Güven, 2020), it is important to use the software effectively in solved examples.

In this study, the triangles and quadrilaterals, measurement of area, polygons, and triangles units of secondary school mathematics textbooks were examined in terms of GHoM for every grade level and every publishing house. This study may be used as a reference for the teachers in selecting the books they will use in their lessons; to take into account, the number of solved examples and GHoM focused in the research. In other words, while choosing the books to be taught in the lessons, teachers should pay attention that the solved examples included in the textbook are descriptive and supportive of the concepts, rather than offering too many exercise type examples. One way to achieve this is that the solved examples address different GHoM. Teachers' activity preferences in the sources/resources to be taught in the lecture can also be investigated. Secondary school students' acquisition of GHoM covered in the solved examples and the problems they encountered in this process can be examined in depth.

Ethics Committee Report: Considering ULAKBİM TRDİZIN criteria (since textbooks are used as a data source and document analysis is performed), an ethical committee report has not been submitted.

Appendix 1. The cover page of the books included in the analysis

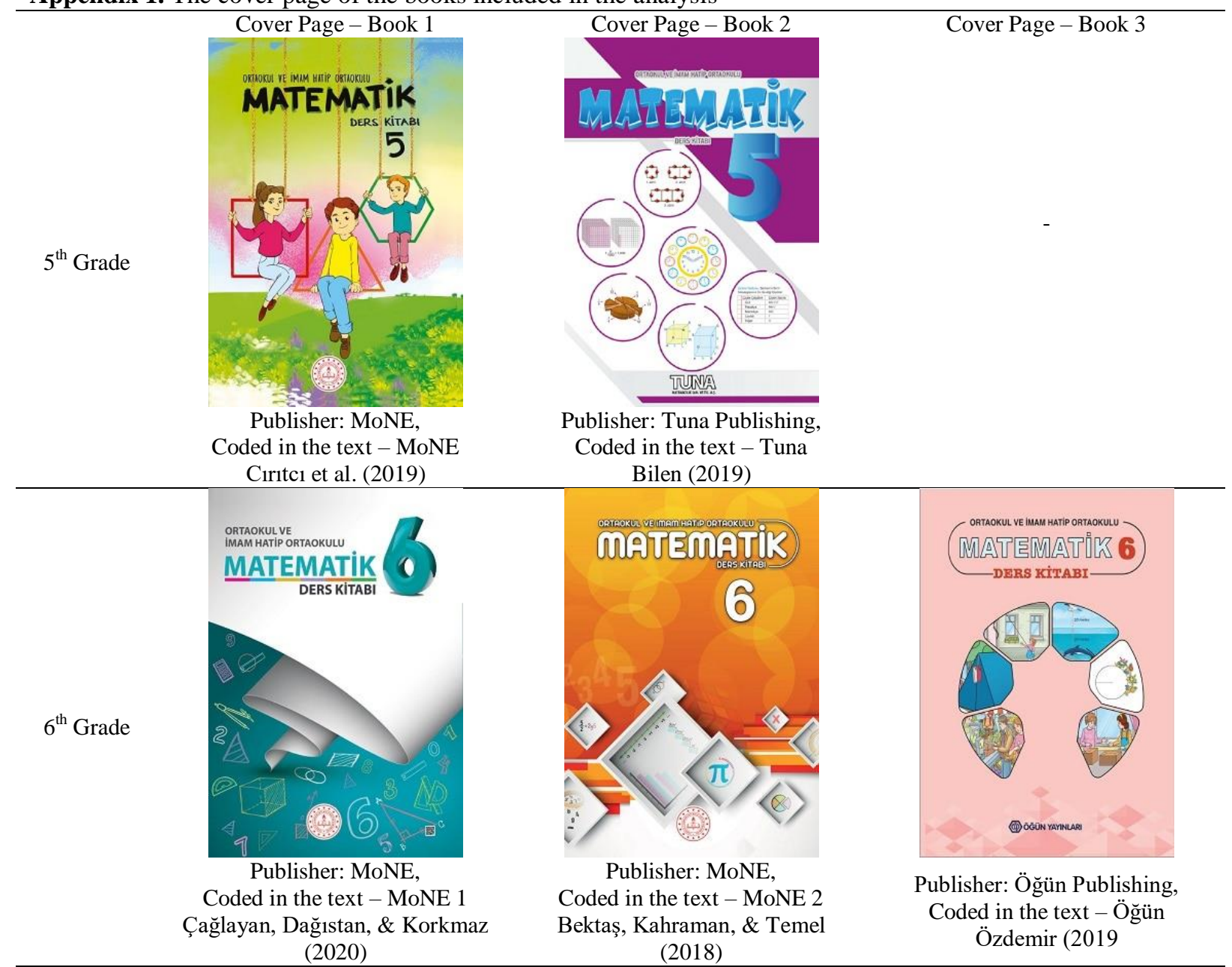


Appendix 1 continued

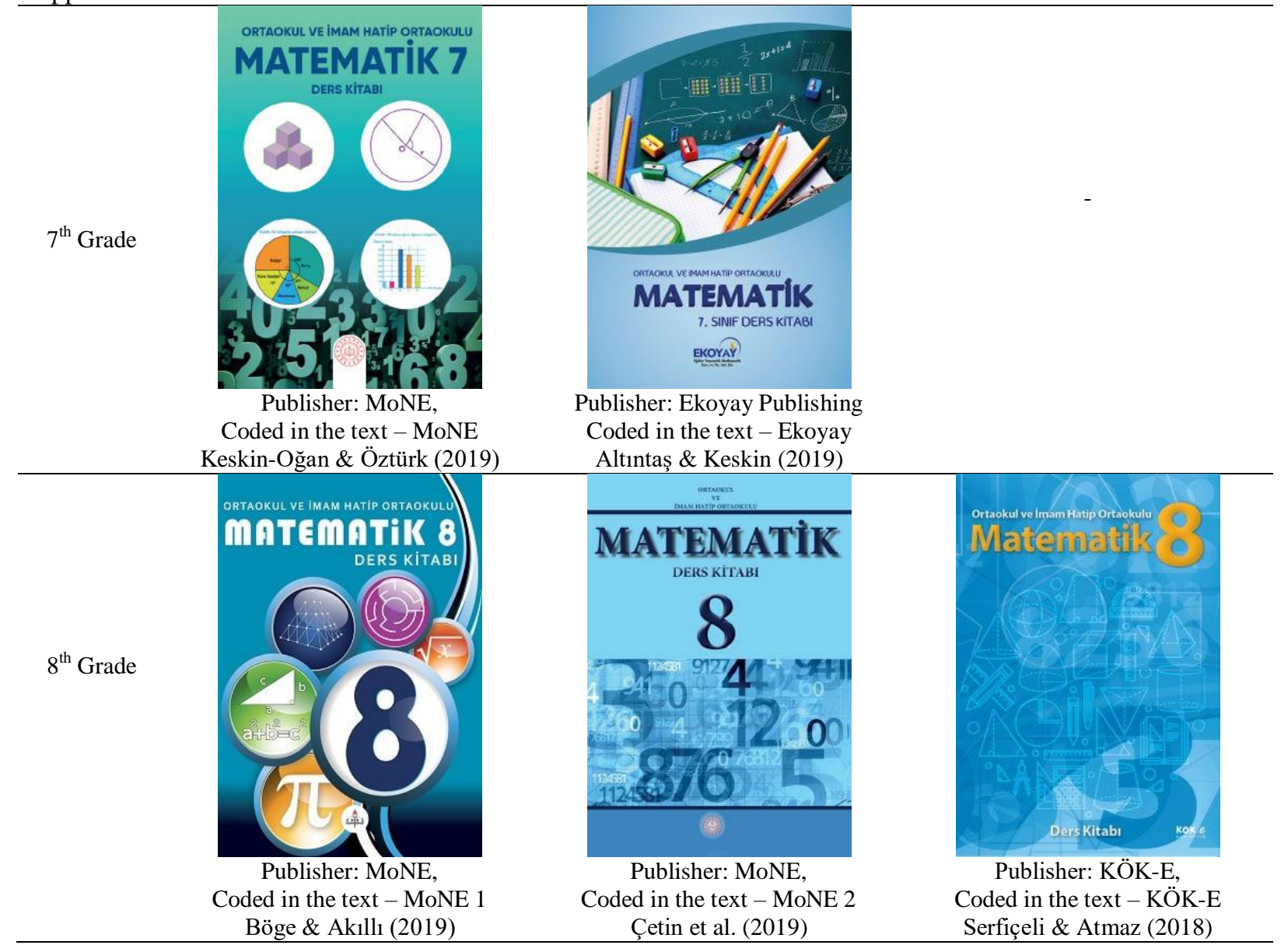




\section{Matematik Ders Kitaplarında Yer Alan Çözümlü Örneklerin Geometrik Düşünme Alışkanlıklarının Kullanımına Yönelik Analizi}

\section{Giriş}

Matematik ve geometri derslerinin öğretilmesinde asıl amaç, öğrencilerde 21. yüzyılın temel becerileri arasında yer alan akıl yürütme, ilişkilendirme, problem çözme, eleştirel düşünme gibi birtakım beceriler kazandırmaktır (Đokić, 2018; Millî Eğitim Bakanlığı [MEB], 2018). Bu becerileri kazandırabilmek, her şeyden önce öğrencilere etkili öğrenme-öğretme ortamlarının hazırlanması ile mümkündür. Öğrenme ortamlarında herkese eşit oranda öğretim sağlanabilecek en etkili materyal de okullarda okutulan ders kitaplarıdır. Ders kitapları eğitim-öğretim faaliyetlerinde en sık kullanılan, öğretim programları ile desteklenen, herkese eşit öğrenme firsatı sunan materyallerden biridir (Akdeniz, 2004; Oikonomidis, 2019; Yılmaz, Seçken ve Morgil, 1998). Dolayısıyla ders kitaplarının istenilen her yaş düzeyine hitap edebilmesi, öğretim programında yer alan kazanımları destekleyebilmesi, yazım kurallarına uygun olması, anlatım dilinin öğrenci seviyelerine uygun olması, ölçme ve değerlendirmelerin amacına hizmet edebilmesi, tasarımının niteliği gibi pek çok özelliklerin ayrı ayrı incelenmesi ve hazırlanması gerekir. İşte bu aşamada hazırlanan öğretim programları doğrultusunda zaman zaman seçilen ders kitaplarının nitelik ve nicelikleri de değişmektedir. Değişen bu niceliklerin karşılanabilmesi, pek çok araştırmacıyı ders kitaplarını incelemeye yöneltmiştir (Alkan ve Güven, 2018; Altun, Arslan ve Yazgan, 2004; Bingölbali ve Bingölbali, 2020; Bütüner, 2020; Fan, 2013; Herbel-Eisenmann, 2007; Kılıç ve Seven, 2002; Kılıçoğlu, 2020; Özkaya ve Duru, 2020; Üredi ve Ulum, 2020; Yaşar, 2005). Söz konusu araştırmalardan bazıları ders kitaplarının ölçme değerlendirme, tasarım, bilimsel içerik vb. özelliklerini incelemeye odaklanırken kimisi de ders kitaplarına yönelik öğretmen ve öğrenci görüşlerine odaklanmıştır (Çelik, Çetinkaya ve Aydoğan-Yenmez, 2020; Korkmaz, Tutak ve İlhan, 2020). Bu özelliklerin dişında matematik ders kitaplarında yer alan problem ç̧̈zme becerilerinin ne şekilde ve hangi yönde çalıştığ 1 da odaklanılması gereken önemli konulardan biri olduğu düşünülmektedir. Çünkü son yıllarda hazırlanan matematik öğretim programlarının merkezinde problem çözme becerilerinin yer alması, matematik ders kitaplarını da o yönde hazırlamaya yönlendirmiştir (MEB, 2018; (National Council of Teachers of Mathematics (NCTM), 2000).

Problem çözme becerisi denildiğinde farklı türde düşünme süreçleri, öğrenme yaklaşımları ve düşünme alışkanlıkları akla gelmektedir. Problem çözme, bireylerin karşılaştığı sorunların üstesinden gelme sürecidir. $\mathrm{Bu}$ kapsamda problem çözmeye dayalı öğretimin, öğrencilerin kavramsal boyutta matematik öğrenmesine yardımcı olmaktadır (Schoenfeld, 1992). Bireylerin problem çözme aşamasında ise karşımıza düşünme alışkanlıkları kavramı çıkmaktadır (Costa \& Kallick, 2009). Düşünme alışkanlıkları, bireylerin zor bir problem ile karşılaştı̆̆ında problemin çözümüne yönelik yaklaşımlarıdır (Costa ve Kallick, 2009; Goldenberg, 1996). Tanımından da anlaşılacağı üzere, problem çözme ile bireylerin düşünme alışkanlıkları iç içedir. Dolayısıyla yapılan çalışmalar bireylerin düşünme alışkanlıkları ile problem çözme başarıları arasında pozitif bir ilişki olduğunu göstermektedir (Bülbül ve Güven, 2019; Bülbül ve Güven, 2020, Bülbül ve Güler, 2021; Driscoll vd., 2007; Driscoll vd., 2008; Erşen, 2018; Gordon, 2011; Marshall, 2004). Literatürde farklı şekillerde düşünme alışkanlıkları tanımlanmıştır. Bu çalışmada matematik ders kitaplarında yer alan çokgenler ve alan ölçme üniteleri inceleneceğinden, geometrik düşünme alışkanlıkları (GDA) teorik yapı olarak ele alınmıştır.

\subsection{Geometrik Düşünme Alışkanlıkları}

Düşünme alışkanlıkları, karşılaşılan bir problemin çözüm yolunun bilinmediği durumlarda devreye giren ve çözüm sürecinde bireye yol gösterici düşünme yöntemleridir (Costa ve Kallick, 2009). Lim ve Selden (2009) düşünme alışkanlıklarını genel ve alana özgü düşünme alışkanlıkları olarak ikiye ayırmıştır. Genel düşünme alışkanlıkları, bireylerin karşılaştığı problemin çözümüne yönelik ilişki arama, deneyim kazanma, denemeler yaparak bir sonuca ulaşmaya çalı̧̧a gibi yaklaşımları içermektedir. Alana özgü düşünme alışkanlıkları ise geometrik, matematiksel, olasılıksal, cebirsel, analitik, bilimsel düşünme alışkanlıkları gibi bir disipline yönelik alışkanlıklardır. Bu çalışmada GDA'lara yönelik inançlar temel alındığından daha çok bu kapsama değinilmiştir.

Genel olarak GDA'lar, denemeler yaparak doğru sonuca ulaşabilme, keşfetme ve yansıtma, uç durumları düşünebilme, değişmezleri inceleme ilişkilendirme, özel durumları düşünebilme, genellemeler yapma şeklindedir (Bülbül, 2016; Cuoco, Goldenberg ve Mark, 1996; Driscoll vd., 2008; Goldenberg, 1996). Her bir alışkanlığın kullanımına bakıldığında aslında geometrik düşünme alışkanlıkları ile problem çözmenin iç içe olduğu görülmektedir. Yani geometrik düşünme alışkanlıkları öğrenciler bir problemle karşılaş̧ı̆̆ında, onların çözüme ulaşma yöntemlerini etkilediği ifade edilmektedir. Bu durumda geometrik düşünme alışkanlıkları bireylerin problemi nasıl çözeceğini bilemediği durumlarda, problemin çözüm yoluna karar verme sürecidir. Driscoll, Wing DiMatteo, Nikula ve Egan (2007) beş ile onuncu sınıflar arasında öğrenim gören öğrencilere uygulayarak geometrik düşünme alışkanlıklarının çatısını ortaya koymuştur. Bu çalışma da Driscoll vd. (2007) tarafından ortaya konun geometrik düşünme alışkanlıkları modeli temel alınarak yürütülmüştür (bkz. Tablo 1). 
Tablo 1. Geometrik Düşünme Alışkanlıkları ve Göstergeleri

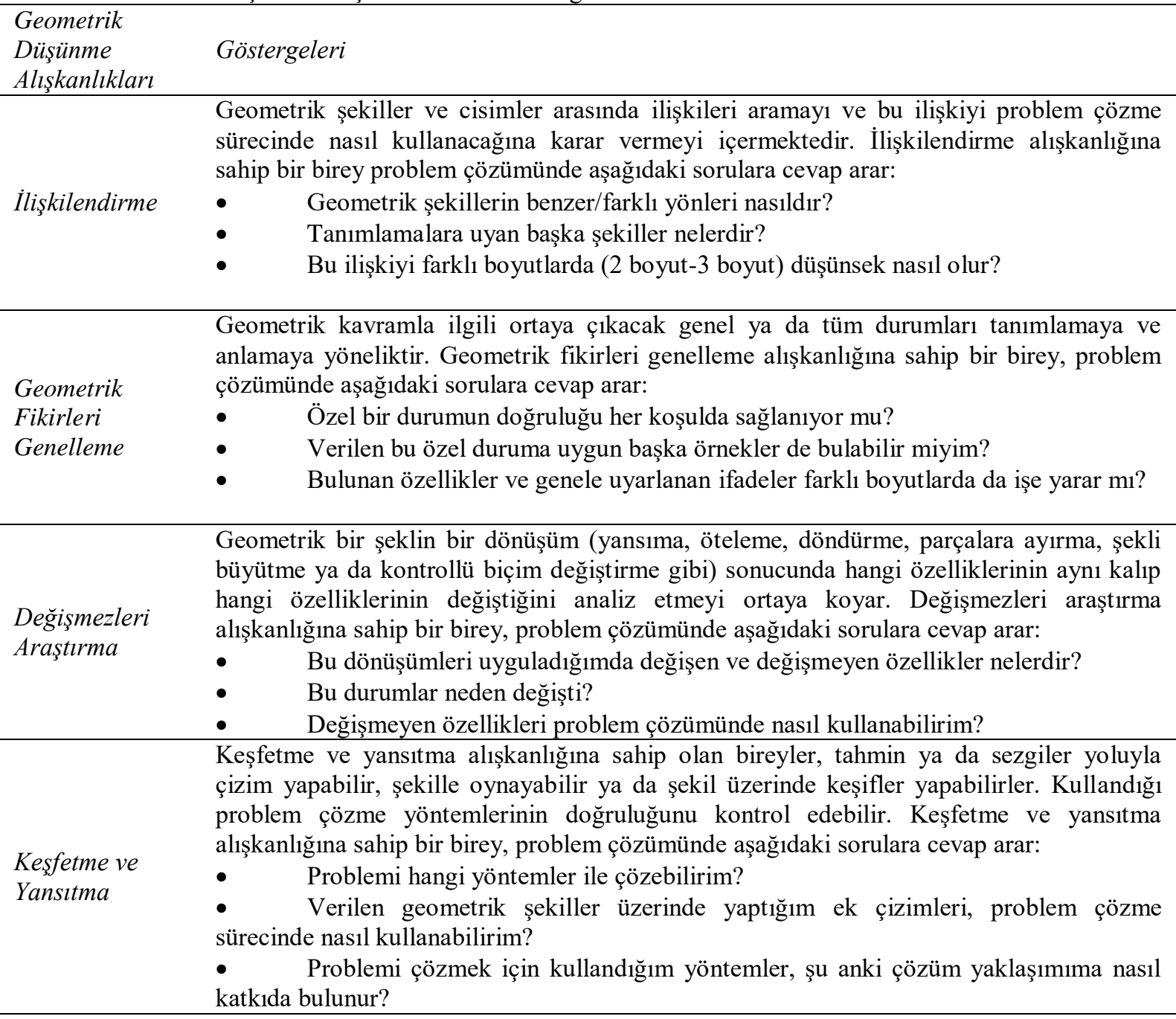

Tablo 1'de ifade edildiği gibi Driscoll vd. (2007) geometrik düşünme alışkanlıklarını; ilişkilendirme, geometrik fikirleri genelleme, değişmezleri araştırma ile keşfetme ve yansıtma olmak üzere dört bölüme ayırmıştır. İlişkilendirme alışkanlığı daha çok geometrik nesnelerin karşılaştırılması, sınıflandırılması, geometrik yapılar arasındaki benzerlik ve farklılıkların belirlenmesi şeklindedir. Geometrik fikirleri genelleme alışkanlığı; özel bir durumun doğruluğunu göstermek ve bu doğruluğu kullanarak genel bir yargıya varmaktır. Değişmezleri araştırma alışkanlığ1 ise verilen geometrik şekillere yapılan dönmüşümler sonucunda değişmeyen özellikleri problemlerin çözümünde kullanmayı içermektedir. Ve son olarak keşfetme ve yansıtma alışkanlığı ise farklı çözüm stratejilerini kullanma, geometrik şekiller üzerinde ek çizimler yapabilme ve yapılan bütün çözümlerin doğruluğunu kontrol edebilme şeklindedir.

GDA, öğrencilerin matematik dersine yönelik başarılarını ve problem çözme başarılarını olumlu ya da olumsuz şekilde etkileyebilmektedir. Matematik derslerini anlatırken en çok ders kitaplarından yararlanıldığ 1 düşünülünce, ders kitaplarında yer alan problemlerin incelenmesine yönelik ihtiyaç ortaya çıkmaktadır. Yukarıda açıklanan GDA'lar arasında hiyerarşik bir düzen ya da döngü söz konusu değildir (Driscoll vd., 2007). Yani bir problemin çözümünde bir öğrenci sadece ilişkilendirme alışkanlığını kullanırken diğer öğrenci aynı problemi hem keşfetme ve yansıtma hem de ilişkilendirme alışkanlığını kullanarak çözebilir. Diğer bir ifade ile bir probleme bakarak hangi geometrik düşünme alışkanlığının kullanıldığına karar veremeyiz. Karar verebilmemiz için problemin çözümlerinin ayrıntılı bir şekilde incelenmesi gerekir. Yani yapılan çözüme göre kullanılan geometrik düşünme alışkanlığı değişebildiğinden dolayı çalışmada matematik ders kitaplarında yer alan çözümlü örnekler incelenmiştir. Bu çalışmada 2020-2021 öğretim yılı itibariyle okutulması kabul edilmiş matematik ders kitaplarının çokgenler ve alan ölçme konularında kullandıkları çözümlü örneklerin GDA'lar kapsamında incelenmesi amaçlanmıştır.

\section{Yöntem}

$\mathrm{Bu}$ çalışmada matematik ders kitapları ayrıntılı bir şekilde tekrar tekrar incelendiğinden ve GDA'ları bağlamında yorumlandığından doküman analizi yöntemi kullanılmıştır. Doküman analizi, ders kitaplarının ya da 
yazılı çalışmaların içeriğinin titizlikle ve sistematik olarak analiz etmek için kullanılan bir yöntemdir (Wach, 2013).

\subsection{Verin Toplanması ve Analizi}

Bu çalışmada Millî Eğitim Bakanlığı tarafından 2020-2021 eğitim-öğretim yılında okutulması kabul edilen bütün ortaokul matematik ders kitapları incelenmiştir. Bu kapsamda beşinci sınıf için MEB ve Tuna yayınevleri, altıncı sınıf kapsamında MEB 1, MEB 2 ve Ögün yayınevleri, yedinci sınıf kapsamında Ekoyay ve MEB yayınevleri, sekizinci sınıf kapsamında ise Kök-e, MEB ve MEB 2 yayınevleri tarafindan basılan matematik ders kitapları incelenmiştir. İlgili kitapların kapak sayfaları Ek 1'de sunulmuştur. Yine bu kitaplardan beşinci sınıfta üçgenler ve dörtgenler ünitesinde, altıncı sınıftan alan ölçme ünitesinde, yedinci sınıftan çokgenler ünitesinde ve sekizinci sınıftan üçgenler ünitesinde yer alan çözümlü problemler GDA içermesi kapsamında incelenmiştir (bkz. Tablo 2). Bu ünitelerin seçilmesinin sebebi, a) Bu ünitelerin en uzun ve en kapsamlı üniteler olması b) Her sınıf seviyesinde geometri ve ölçme alanlarında farklı bölüm ve ünitelerin olması ancak hepsini aynı anda içerebilecek en kapsamlı ünitelerin bunlar olmasıdır.

Tablo 2. Matematik Ders Kitapları ve İncelenen Üniteler

\begin{tabular}{ccc}
\hline Sinıf & Yayinevleri & Üniteler \\
\hline \multirow{2}{*}{ 5. sinıf } & MEB & Üçgenler ve Dörtgenler \\
\cline { 2 - 3 } & TUNA & Üçgenler ve Dörtgenler \\
\cline { 2 - 3 } 6. sinıf & MEB 1 & Alan Ölçme \\
\cline { 2 - 3 } & MEB 2 & Alan Ölçme \\
\hline \multirow{2}{*}{ 7. sinıf } & ÖĞ̈̈N & Alan Ölçme \\
\cline { 2 - 3 } & MEB & Çokgenler \\
\hline \multirow{2}{*}{ 8. sinıf } & EKOYAY & Çokgenler \\
& MEB 1 & Üçgenler \\
\cline { 2 - 3 } & MEB 2 & Üçgenler \\
\hline
\end{tabular}

Tablo 2'de görüldüğü gibi iki beşinci sınıf, üç altıncı sınıf, iki yedinci sınıf, üç sekizinci sınıf olmak üzere toplam 10 matematik ders kitabında yer alan çözümlü örnekler incelenmiştir. Çözümlü örnekler her bir araştırmacı tarafindan ayrı ayrı incenmiş ve iki araştırmacı tarafından Tablo 1'de sunulan ve Driscoll ve diğerleri (2007) tarafından geliştirilen GDA ve göstergeler, göz önünde bulundurularak ayrı ayrı kodlanmıştır. Daha sonra verilen kodlar karşılaştırılarak elde edilen güvenirlik analizi sonucunda, güvenirlik katsayısı 0.82 bulunmuştur. Farklılaşan kodlar için araştırmacılar tarafından fikir birliği sağlanana kadar tartışma yürütülmüştür. Ortak kodlar oluşturulduktan sonra veriler tablolar halinde sunulmuştur. Şekil 1, örnek bir çözümlü problem ve geometrik düşünme alışkanlığının kullanımına yönelik analizi içermektedir.

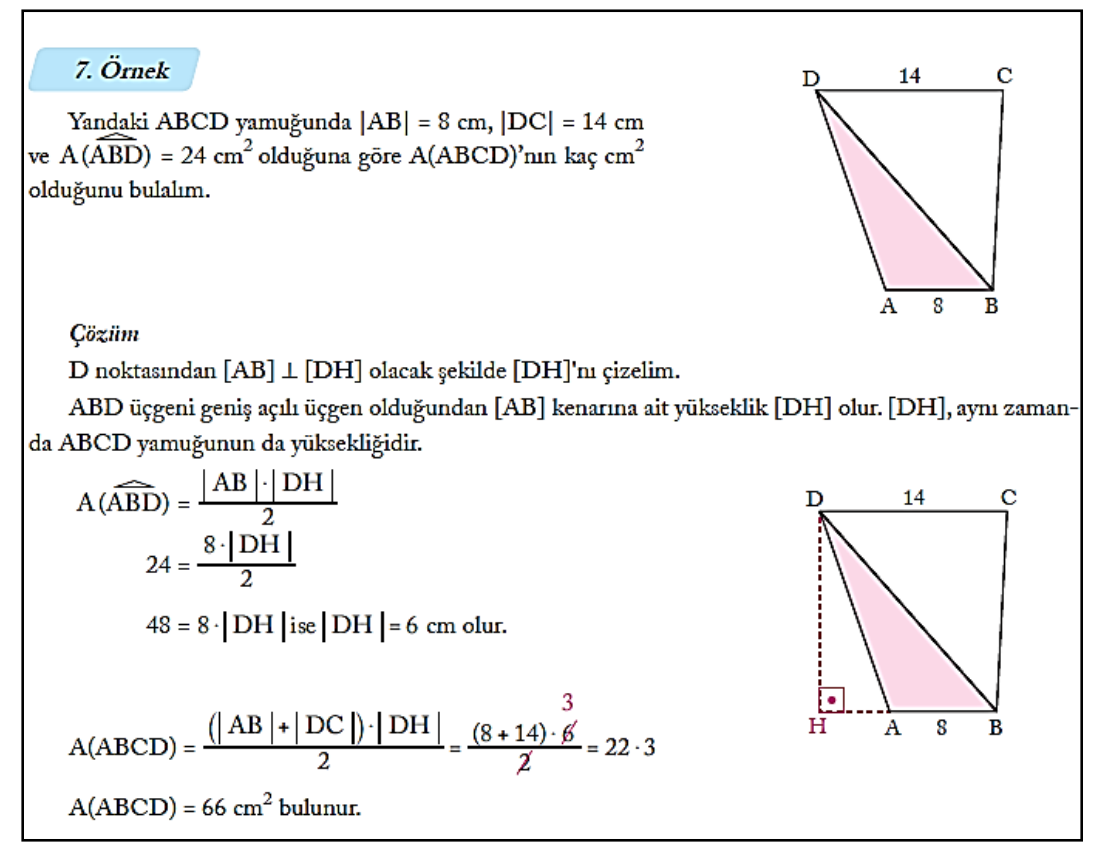

Şekil 1. Yedinci sınıf Ekoyay yayınlarında yer alan bir çözümlü örnek 
Şekil 1'de yer alan örnekte bir ABCD yamuğunun ve belirli kenarların uzunluklarının verilmiş ve yamuğun alanı sorulmuştur. Yapılan çözüm incelendiğinde öncelikle yamuğa D noktasından bir dikme indirilerek dörtgene tamamlandığı görülmektedir. Bu aşamada şekil üzerinde ek bir çizim yapıldığından keşfetme ve yansıtma alışkanlığı kullanılmıştır. Çözümün devamı incelendiğinde, istenilen yamuğun alanı bulunurken kenarlar ve yükseklik arasında ilişkilendirme yapıldığı görülmektedir. Dolayısıyla bu aşamada da çözümde ilişkilendirme alışkanlığı kullanılmıştır. Sonuç olarak bu örnek İlişkilendirme+Keşfetme ve yansıtma şeklinde kodlanmıştır.

\section{Bulgular}

Bu çalışmada matematik ders kitaplarında yer alan çözümlü örneklerin GDA'lara göre analizi incelenmiştir. Bu kapsamda öncelikle çözümlü örneklerin sayısının GDA'lara ve yayın evlerine göre dağılımları incelenmiştir (bkz. Tablo 2).

Tablo 2. Matematik Ders Kitaplarında Yer Alan Çözümlü Örneklerin Genel Analizi

\begin{tabular}{ccccc}
\hline & Yayınevi & Ünite Adı & $\begin{array}{c}\text { Çözümlü Örnek } \\
\text { Sayısı }\end{array}$ & $\begin{array}{c}\text { Kullanılan Geometrik } \\
\text { Düşünme Alışkanlığı Sayısı }\end{array}$ \\
\hline \multirow{2}{*}{ 5. Sınıf } & MEB & Üçgenler ve Dörtgenler & 22 & 34 \\
\cline { 2 - 5 } & TUNA & Üçgenler ve Dörtgenler & 20 & 26 \\
\hline \multirow{3}{*}{ 6. Sinıf } & MEB 1 & Alan Ölçme & 21 & 34 \\
\cline { 2 - 5 } & MEB 2 & Alan Ölçme & 23 & 39 \\
\hline \multirow{2}{*}{ 7. Sinıf } & MË̈N & Alan Ölçme & 32 & 50 \\
\cline { 2 - 5 } & EKOYAY & Çokgenler & 49 & 77 \\
\hline \multirow{3}{*}{ 8. Sinıf } & MEB 1 & Çokgenler & 70 & 87 \\
\cline { 2 - 5 } & MEB 2 & Üçgenler & 48 & 41 \\
\cline { 2 - 5 } & KÖK-E & Üçgenler & 24 & 51 \\
\hline
\end{tabular}

Tablo 2 incelendiğinde, en çok çözümlü örnek sayısının yedinci sınıfa ait olduğu görülmektedir. Özellikle 7. Sınıfta yer alan Ekoyay yayınevi "Çokgenler” ünitesine ait 70 çözümlü örnek, MEB yayınevi ise aynı üniteye ait 49 çözümlü örnek vermiştir. En az çözümlü örnek sayısının yer aldığı sınıf ise beşinci ve altıncı sınıflardadır. Beşinci sınıfta yer alan MEB yayınevi “Üçgenler ve Dörtgenler” ünitesine ait 22 çözümlü örnek, yine aynı sınıf ve üniteye sahip Tuna yayınevi ise 20 çözümlü örnek vermiştir. Benzer şekilde altıncı sınıfta yer alan MEB 1 yayınevi "Alan Ölçme” ünitesine ait 21 çözümlü örnek, MEB 2 yayınevi aynı üniteye ait 23 çözümlü örnek ve son olarak Öğün yayınevi ise aynı üniteye ait 32 çözümlü örnek vermiştir. Tablo 2'de dikkat çeken bir diğer bulgu da kullanılan GDA'ların çözümlü örnek sayılarından daha fazla olmasıdır. Yani sırasıyla beşinci sınıfın MEB yayın evine ait 22 çözümlü örnek varken 34 geometrik düşünme alışkanlığı, Tuna yayınevine ait 20 çözümlü örnek varken 26 geometrik düşünme alışkanlığı kullanıldığı görülmektedir. Benzer şekilde altınc1 sınıfta MEB 1 yayınevine ait 21 çözümlü örnek yer alırken 34 geometrik düşünme alışkanlığı, MEB 2 yayınevinde 23 çözümlü örnek yer alırken, 39 geometrik düşünme alışkanlığı, Öğün yayınevinde 32 çözümlü örnek yer alırken, 50 geometrik düşünme alışkanlığı kullanılmıştır. Yedinci sınıfta Ekoyay yayınevinde 70 çözümlü örneğe karşılık 87 geometrik düşünme alışkanlığı, MEB yayınevinde 49 çözümlü örneğe karşılık 77 geometrik düşünme alışkanlığı verilmiştir. Son olarak sekizinci sınıfa yer alan Kök-e yayınevinin kullandı̆̆ 28 çözümlü örnek $51 \mathrm{kez}$ geometrik düşünme alışkanlığı kullanılarak, MEB 2 yayınevinin kullandığ 24 çözümlü örnek 41 kez geometrik düşünme alışkanlığı kullanılarak, MEB 1 yayınevinin kullandığ1 48 çözümlü örnek 84 kez geometrik düşünme alışkanlığı kullanılarak çözüldüğü görülmektedir.

\subsection{Beşinci Sınıf Matematik Ders Kitaplarında Yer Alan Çözümlü Örneklerin Analizi}

Beşinci sınıf matematik ders kitaplarında yer alan çözümlü örneklerin GDA kullanımına yönelik analizine Tablo 3'de yer verilmiştir.

Tablo 3. Beşinci sınıf matematik ders kitaplarında yer alan çözümlü örneklerin analizi

\begin{tabular}{|c|c|c|c|c|c|c|c|c|c|c|c|}
\hline & & \multicolumn{2}{|c|}{ İlişkilendirme } & \multicolumn{2}{|c|}{$\begin{array}{c}\text { Geometrik Fikirleri } \\
\text { Genelleme }\end{array}$} & \multicolumn{2}{|c|}{$\begin{array}{l}\text { Değişmezleri } \\
\text { Araştırma }\end{array}$} & \multicolumn{2}{|c|}{$\begin{array}{l}\text { Keşfetme ve } \\
\text { Yansitma }\end{array}$} & \multicolumn{2}{|c|}{$\begin{array}{l}\text { Alışkanlık } \\
\text { Gözlenmedi }\end{array}$} \\
\hline & & $\mathrm{f}$ & $\%$ & $\mathrm{f}$ & $\%$ & $\mathrm{f}$ & $\%$ & $\mathrm{f}$ & $\%$ & f & $\%$ \\
\hline \multirow{2}{*}{ 5. sinif } & MEB & 21 & 61.76 & 2 & 5.88 & 2 & 5.88 & 8 & 23.53 & 1 & 2.95 \\
\hline & Tuna & 20 & 76.92 & - & - & - & - & 6 & 23.08 & - & - \\
\hline
\end{tabular}


Tablo 3 incelendiğinde MEB yayınevinde yer alan çözümlü örneklerin \%61.76'sında ilişkilendirme, \%23.53'ünde keşfetme ve yansıtma, \%5.88'inde değişmezleri araştırma, \%5.88'inde geometrik fikirleri genelleme alışkanlıklarını kullandıkları görülmektedir. Tuna yayınevinde yer alan çözümlü örneklerin ise \%76.92'sinde ilişkilendirme, \%23.07'sinde keşfetme ve yansıtma alışkanlıklarını kullanmıştır. Tuna yayınevinde yer alan çözümlü örneklerin hiçbirisinde geometrik fikirleri genelleme ile değişmezleri araştırma alışkanlığına rastlanmamıştır. Her iki yayınevinde de en çok ilişkilendirme ikinci olarak ise keşfetme ve yansıtma alışkanlığı kullanılmıştır. Çözümlü örneklerde ilişkilendirme alışkanlığı genel olarak; verilen geometrik şekillerin alanlarıçevresi-kenar uzunlukları arasında ilişki kurma, çokgenlerin iç açılarını karşılaştırma ya da dörtgenler arasında ilişkiler kurma şeklinde olduğu gözlenmiştir (bkz. Şekil 2).

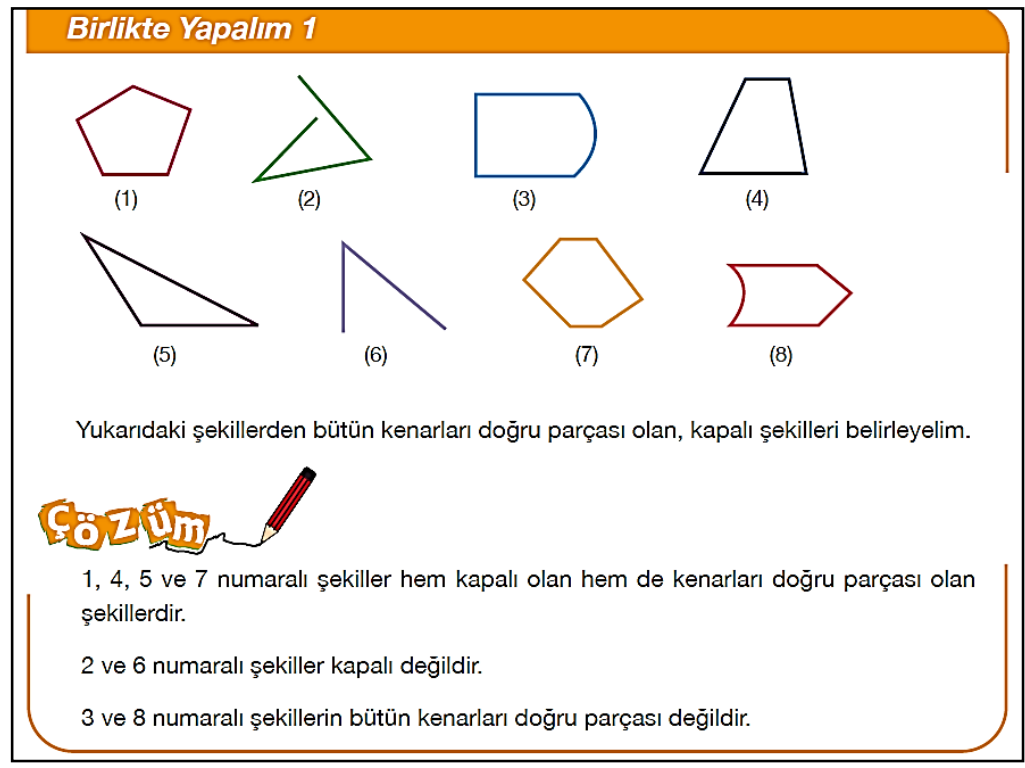

Şekil 2. Beşinci sınıf MEB yayınevinde yer alan çözümlü örnek

Şekil 2'de “yukarıdaki şekillerden bütün kenarları doğru parçası olan kapalı şekilleri belirleyelim” şeklinde çözümlü örnek yer almaktadır. Bu örneğin çözümü incelendiğinde geometrik şekillerin kapalı olması ile kenarlarının ilişkilendirildiği görülmektedir. Dolayısıyla bu örneğin çözümünde ilişkilendirme alışkanlığı yer almaktadır. Bazı örneklerin çözümünde ilişkilendirme alışkanlığı tek başına kullanılırken bazı örneklerin çözümünde ilişkilendirme alışkanlığı keşfetme ve yansıtma alışkanlığı ile birlikte kullanılmıştır. Şekil 3'de bu duruma benzer bir örnek verilmiştir.

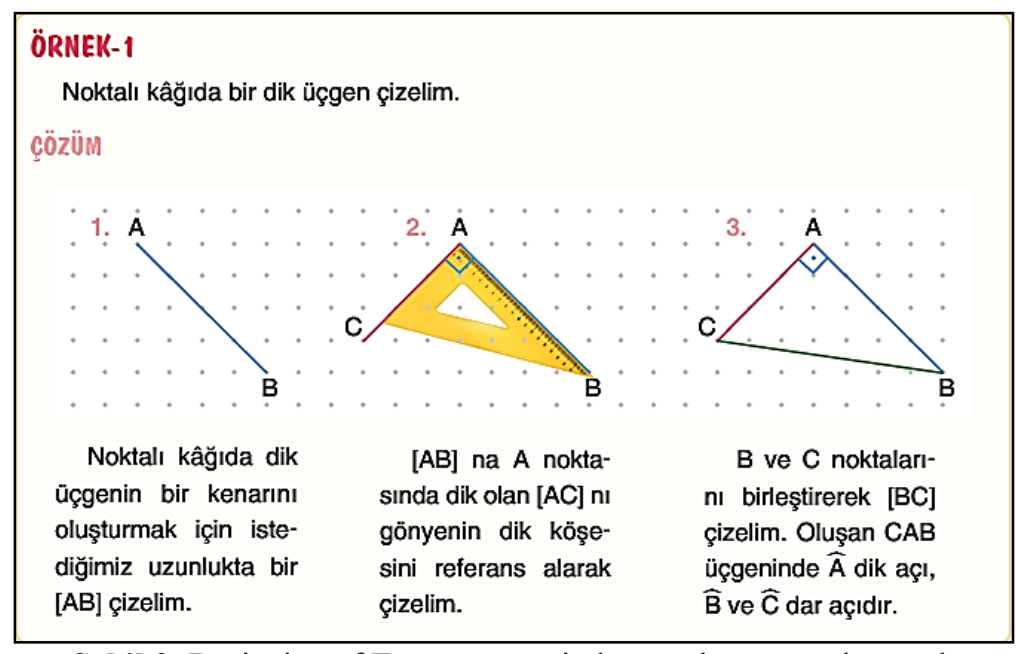

Şekil 3. Beşinci sınıf Tuna yayınevinde yer alan çözümlü örnek

Şekil 3 'te yer alan çözüm incelendiğinde bir cetvel yardımıyla dik üçgen çizildiği görülmektedir. Bu çizimi yaparken noktalı kâğıttan ve cetvelin kenar uzunluklarının özelliklerinden yararlanıldığı gözlenmiştir. Bu aşamada noktalar arası uzaklığın ve cetvelin dik açı oluşturma kısmı ile üçgenin kenarlarının ilişkilendirilmesi ile ilişkilendirme alışkanlığı, ek bir çizim yapılması ile de keşfetme ve yansıtma alışkanlığı kullanılmıştır. Beşinci sınıf matematik kitaplarında yer alan bazı örneklerde yer alan çözümlerde ise ilişkilendirme alışkanlığ diğer geometrik düşünme alışkanlıklar ile birlikte kullanılmıştır (bkz. Şekil 4). 


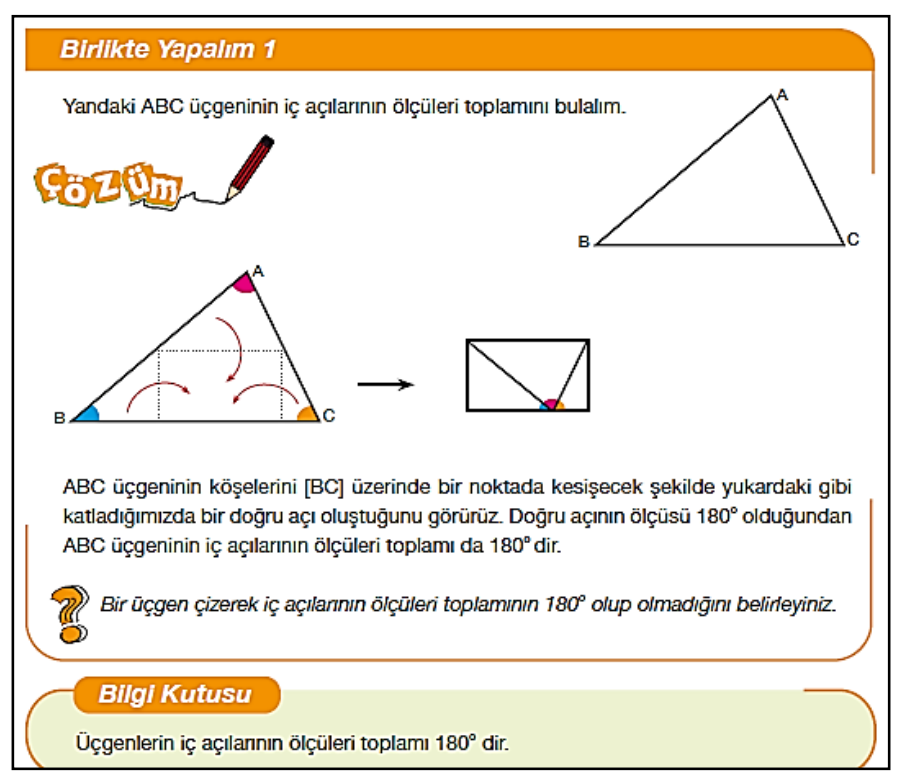

Şekil 4. Beşinci sınıf MEB yayınevinde yer alan çözümlü örnek

Şekil 4'de yer alan örneğin çözümü incelendiğinde üçgenin kenarları üzerinden katlama yapılıp, katlanan üçgenlerin dikdörtgenin kenarına yerleştirildiği görülmektedir. Katlama yapılırken aslında geometrik şeklin görünüşünde bir değişiklik yapılmıştır. Dolayısıyla şeklin manipüle edilmesi ve değişmeyen özelliklerin çözümde kullanılması ile değişmezleri araştırma alışkanlığı, katlanan üçgenlerin açıları ile ilişki kurulması ile ilişkilendirme, yeni bir şeklin çözüm sürecine katılması ile keşfetme ve yansıtma, özel bir durumu kullanarak genel bir kural oluşturma ile de (üçgenin iç açıları toplamı $180^{\circ}$ dir) geometrik fikirleri genelleme alışkanlığ kullanılmıştır. Dolayısıyla bu örnekte görüldüğü gibi bazı çözümlerde GDA’ların hepsi kullanılabilmektedir. Beşinci sınıf matematik ders kitaplarında bir tane örneğin çözümünde ise herhangi bir geometrik düşünme alışkanlığına rastlanmamıştır (bkz. Şekil 5).

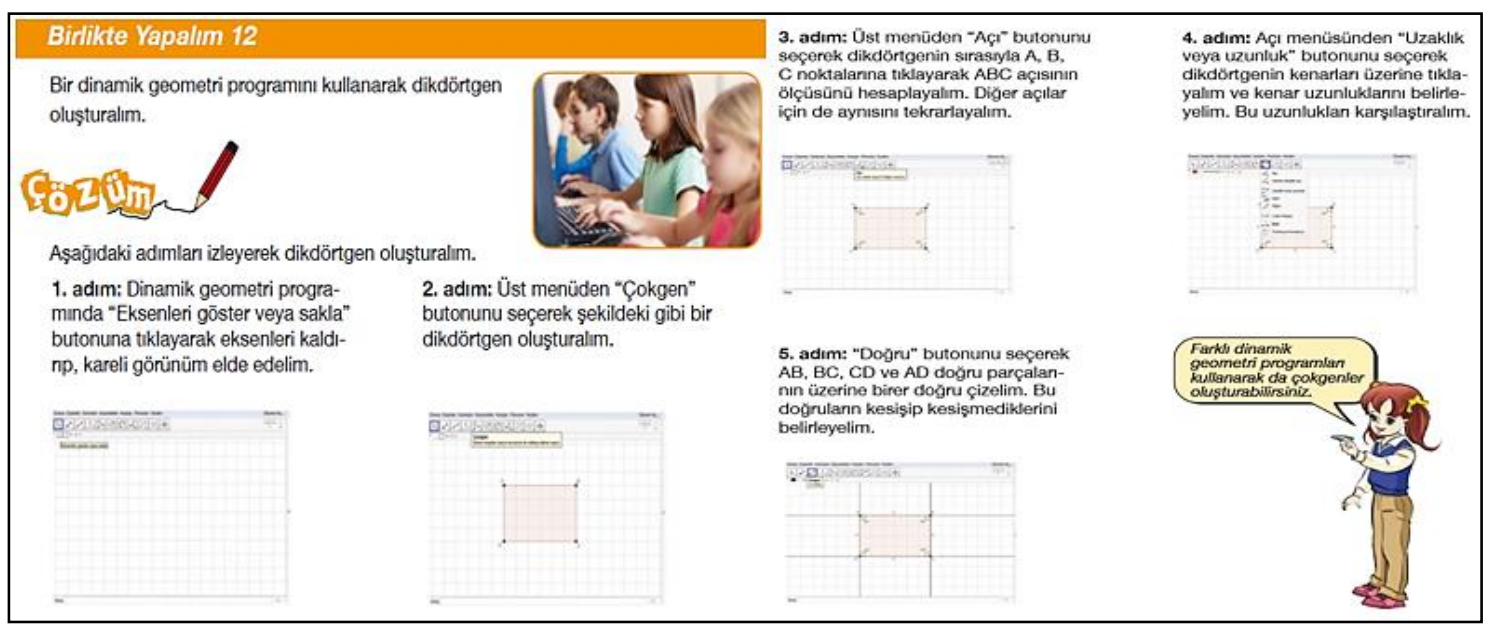

Şekil 5. Beşinci sınıf MEB yayınevinde yer alan çözümlü örnek

Şekil 5'te yer alan örneğin çözümde, öğrencilerden bir dinamik geometri yazılımı kullanılarak dikdörtgen oluşturması istenmektedir. Kitabın herhangi bir bölümünde bu yazılım ile ilgili bir bilgilendirme verilmemiştir. Dolayısıyla beşinci sınıf öğrencilerinin bu yazılımı kullanma becerisine sahip olmadığı bilinmemektedir. Ayrıca yapılan çözümde geometri yazılımında bütün adımlar tek tek açıklanmış, öğrenciyi herhangi bir düşünme alışkanlığını kullanmaya yöneltilmemiştir. Bütün bunların sonucunda yukarıda verilen örnek araştırmacılar tarafından herhangi bir alışkanlık gözlenmedi şeklinde kodlanmıştır.

\subsection{Altıncı Sınıf Matematik Ders Kitaplarında Yer Alan Çözümlü Örneklerin Analizi}

Altıncı sınıf matematik ders kitaplarında yer alan çözümlü örneklerin GDA kullanımına yönelik analizine Tablo 4'de yer verilmiştir. 
Tablo 4. Altıncı sınıf matematik ders kitaplarında yer alan çözümlü örneklerin analizi

\begin{tabular}{|c|c|c|c|c|c|c|c|c|c|c|c|}
\hline & & \multicolumn{2}{|c|}{ İlişkilendirme } & \multicolumn{2}{|c|}{$\begin{array}{c}\text { Geometrik } \\
\text { Fikirleri } \\
\text { Genelleme }\end{array}$} & \multicolumn{2}{|c|}{$\begin{array}{c}\text { Değişmezleri } \\
\text { Araştırma }\end{array}$} & \multicolumn{2}{|c|}{$\begin{array}{l}\text { Keşfetme ve } \\
\text { Yansitma }\end{array}$} & \multicolumn{2}{|c|}{$\begin{array}{l}\text { Alışkanlık } \\
\text { Gözlenmedi }\end{array}$} \\
\hline & & $\mathrm{f}$ & $\%$ & $\mathrm{f}$ & $\%$ & $\mathrm{f}$ & $\%$ & f & $\%$ & $\mathrm{f}$ & $\%$ \\
\hline \multirow{3}{*}{ 6. $\sin 1 f$} & MEB1 & 20 & 58.82 & & & 2 & 5.88 & 12 & 35.3 & & \\
\hline & MEB 2 & 23 & 58.99 & 1 & 2.56 & 3 & 7.69 & 12 & 30.76 & & \\
\hline & ÖĞÜN & 29 & 58 & 3 & 6 & 3 & 6 & 15 & 30 & & \\
\hline
\end{tabular}

Tablo 4 incelendiğinde MEB1 yayınevinde yer alan çözümlü örneklerin \%58.82'sinde ilişkilendirme, \%35.29'unda keşfetme ve yansıtma, \%5.88'inde değişmezleri araştırma alışkanlıklarının kullanıldı̆̆ görülmektedir. MEB 2 yayınevinde yer alan çözümlü örnekler incelendiğinde ise \%58.97'sinin ilişkilendirme alışkanlığından, \%30.76'sının keşfetme ve yansıtma alışkanlığından, \%7.69'unun değişmezleri araştırma alışkanlığından, \%2.56'sının ise geometrik fikirleri genelleme alışkanlığından oluşmaktadır. Son olarak Öğün yayınevinin örnekleri incelendiğinde çözümlerin \%58'inin ilișkilendirme alışkanlığını kullanmaya, \%30'unun keşfetme ve yansıtma alışkanlığını kullanmaya, \%6'sının değişmezleri araştırma ve diğer \%6sının ise geometrik fikirleri genelleme alışkanlığını kullanmaya yönelik olduğu görülmektedir. Bunun dışında altıncı sınıfta yer alan matematik ders kitaplarında geometrik düşünme alışkanlığı gözlenmeyen çözümlü örnek yer almamaktadır. Altıncı sınıf MEB1 ve MEB2 yayınevlerinin kitaplarında yer alan çözümlü örnekler genellikle günlük hayatla ilişkilendirilmiştir (bkz. Şekil 6).

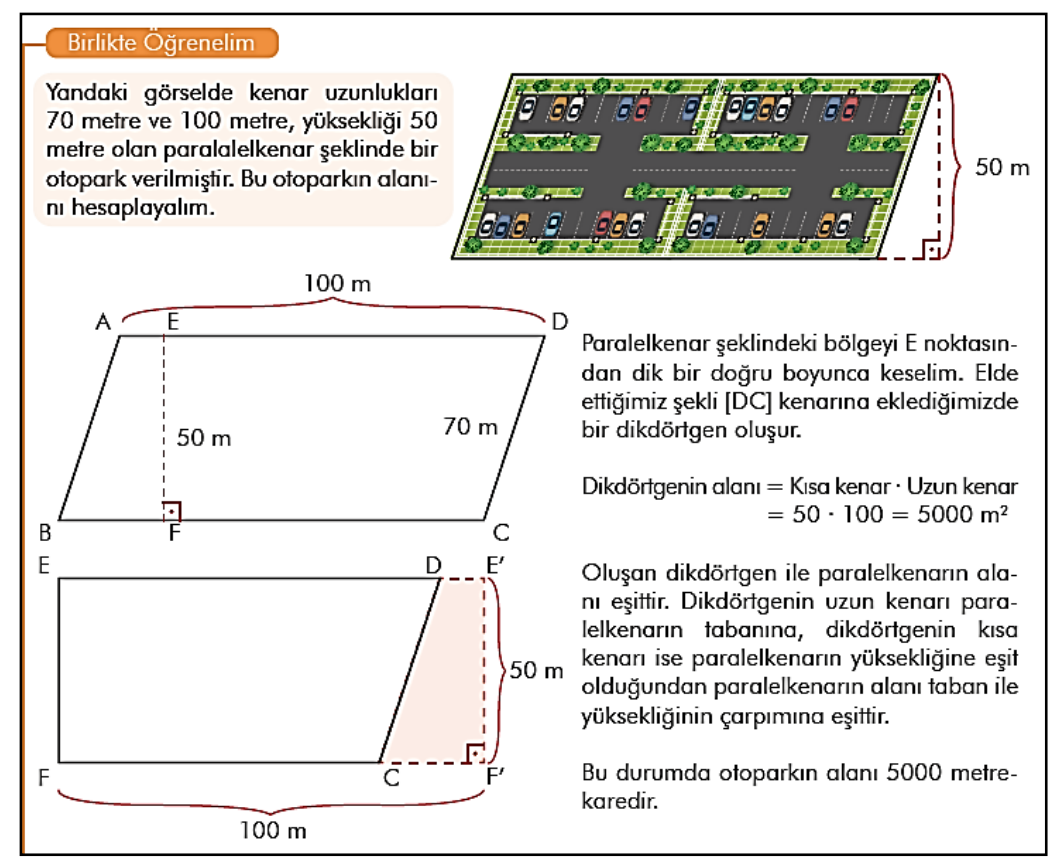

Şekil 6. Altıncı sınıf MEB 1 kodlu yayınevinde yer alan çözümlü örnek

Altıncı sınıf MEB1 yayınevinde yer alan ve Şekil 6'da verilen örnek incelendiğinde, örneğin günlük hayatla ilişkili olduğu görülmektedir. Bunun yanında örneği çözerken verilen paralelkenar şeklinin bir kenarından yamuk şekli kesilerek diğer kenarına eklenmiştir. Bu yöntemle dikdörtgen şekli elde edildikten sonra istenilen bulunmuştur. $\mathrm{Bu}$ aşamada yamuk şeklinin kesilip diğer tarafa eklenmesi ile değişmezleri araştırma ile keşfetme ve yansıtma alışkanlıkları kullanılmıştır. Ayrıca verilen kenar uzunlukları ile alan arasında ilişki kurularak ilişkilendirme alışkanlığı da kullanılmıştır. Dolayısıyla Şekil 6'da yer alan örneğin çözümünde keşfetme ve yansıtma, ilişkilendirme, değişmezleri araştırma alışkanlıkları kullanılmış olur.

\subsection{Yedinci Sınıf Matematik Ders Kitaplarında Yer Alan Çözümlü Örneklerin Analizi}

Yedinci sınıf matematik ders kitaplarında yer alan çözümlü örneklerin GDA kullanımına yönelik analizine Tablo 5'te yer verilmiştir. 
Tablo 5. Yedinci sınıf matematik ders kitaplarında yer alan çözümlü örneklerin analizi

\begin{tabular}{|c|c|c|c|c|c|c|c|c|c|c|c|}
\hline & & \multicolumn{2}{|c|}{ İlişkilendirme } & \multicolumn{2}{|c|}{$\begin{array}{c}\text { Geometrik } \\
\text { Fikirleri } \\
\text { Genelleme }\end{array}$} & \multicolumn{2}{|c|}{$\begin{array}{c}\text { Değişmezleri } \\
\text { Araştırma }\end{array}$} & \multicolumn{2}{|c|}{$\begin{array}{c}\text { Keşfetme ve } \\
\text { Yansitma }\end{array}$} & \multicolumn{2}{|c|}{$\begin{array}{l}\text { Alışkanlık } \\
\text { Gözlenmedi }\end{array}$} \\
\hline & & $\mathrm{f}$ & $\%$ & $f$ & $\%$ & $f$ & $\%$ & $\mathrm{f}$ & $\%$ & $\mathrm{f}$ & $\%$ \\
\hline \multirow{2}{*}{ 7. sinif } & MEB & 44 & 57.16 & 6 & 7.79 & 3 & 3.89 & 19 & 24.67 & 5 & 6.49 \\
\hline & EKOYAY & 59 & 67.83 & 4 & 4.59 & & & 13 & 14.94 & 11 & 12.64 \\
\hline
\end{tabular}

Tablo 5 incelendiğinde Ekoyay yayınevinde yer alan çözümlü örneklerin \%67.81'inde ilişkilendirme, \%14.94'ünde keşfetme ve yansıtma, \%4.59'unda geometrik fikirleri genelleme alışkanlıklarının kullanıldığ görülmektedir. Ayrıca \%12.64'ünde ise herhangi bir geometrik düşünme alışkanlığına rastlanmamıştır. MEB yayınevinde yer alan çözümlü örneklerin ise \%57.14'ünde ilişkilendirme, \%24.67'sinde keşfetme ve yansitma, \% 7.79'unda geometrik fikirleri genelleme, \%3.89'unda ise değişmezleri araştırma alışkanlıkları kullanılmıştır. Yine MEB yayınevinde yer alan çözümlü örneklerin \%6.49'unda herhangi bir geometrik düşünme alışkanlığının kullanımına rastlanmamıştır. Yedinci sınıfta yer alan çözümlü örneklerde de en çok ilişkilendirme ile keşfetme ve yansıtma alışkanlıklarının kullanıldığı dikkat çekmektedir. Yedinci sınıfta verilen örneklerin genelinde ilişkilendirme ile keşfetme ve yansıtma alışkanlıkları birlikte kullanılmıştır. Şekil 7'de bu duruma uygun bir örnek yer almaktadır.

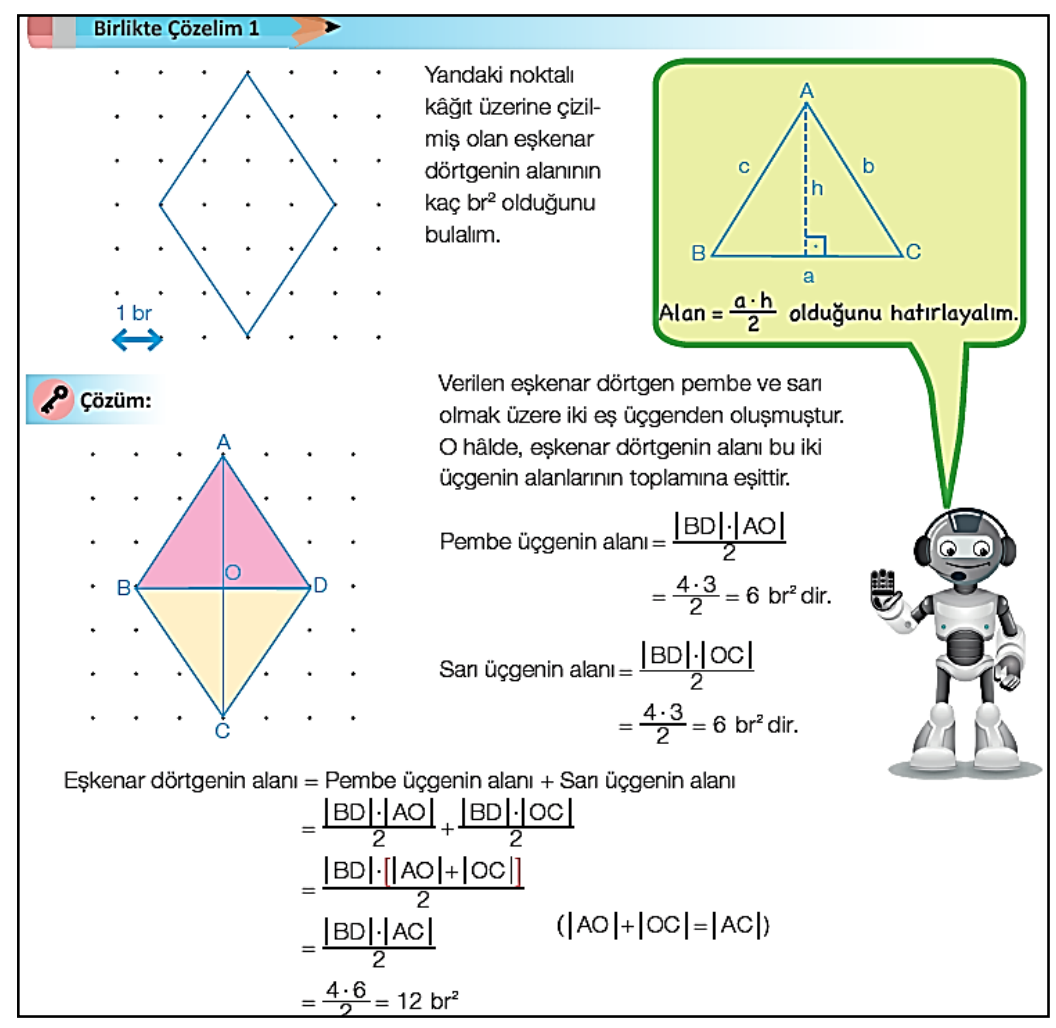

Şekil 7. Yedinci sınıf MEB yayınevinde yer alan çözümlü örnek

MEB yayınevinin Şekil 7'de yer alan çözümlü örneği incelendiğinde, eşkenar dörtgenin köşegenleri çizilerek, üçgenlerin alanları ile eşkenar dörtgenin alanı ilişkilendirilmiş ve doğru sonuca ulaşılmıştır. Bu aşamada ek çizimler kullanıldığından keşfetme ve yansıtma alışkanlığ 1 , üçgenin alanı ile eşkenar dörtgenin alanı ilişkilendirildiğinden ilişkilendirme alışkanlığı kullanılmıştır. Bazı durumlarda ilişkilendirme alışkanlığı geometrik fikirleri genelleme ile keşfetme ve yansıtma alışkanlığı ile kullanılmıştır (bkz. Şekil 8).

Şekil 8'de yer alan çözümlü örnek çokgenlerin dış açıların ölçülerinin toplamını bulmaya yöneliktir. Bu kapsamda ilk önce üçgenin daha sonra beşgenin dış açıların ölçüsü bulunmuştur. Dış açıların ölçüleri bulunurken geometrik şekillerin çizimleri yapıldığından keşfetme ve yansıtma alışkanlığı kullanılmıştır. Çözümde üçgen ve dörtgenler üzerinden doğruluğu gösterildikten sonra bütün çokgenler için genel bir kural oluşturulmuştur. Bu aşamada da geometrik fikirleri genelleme alışkanlığı kullanılmıştır. 


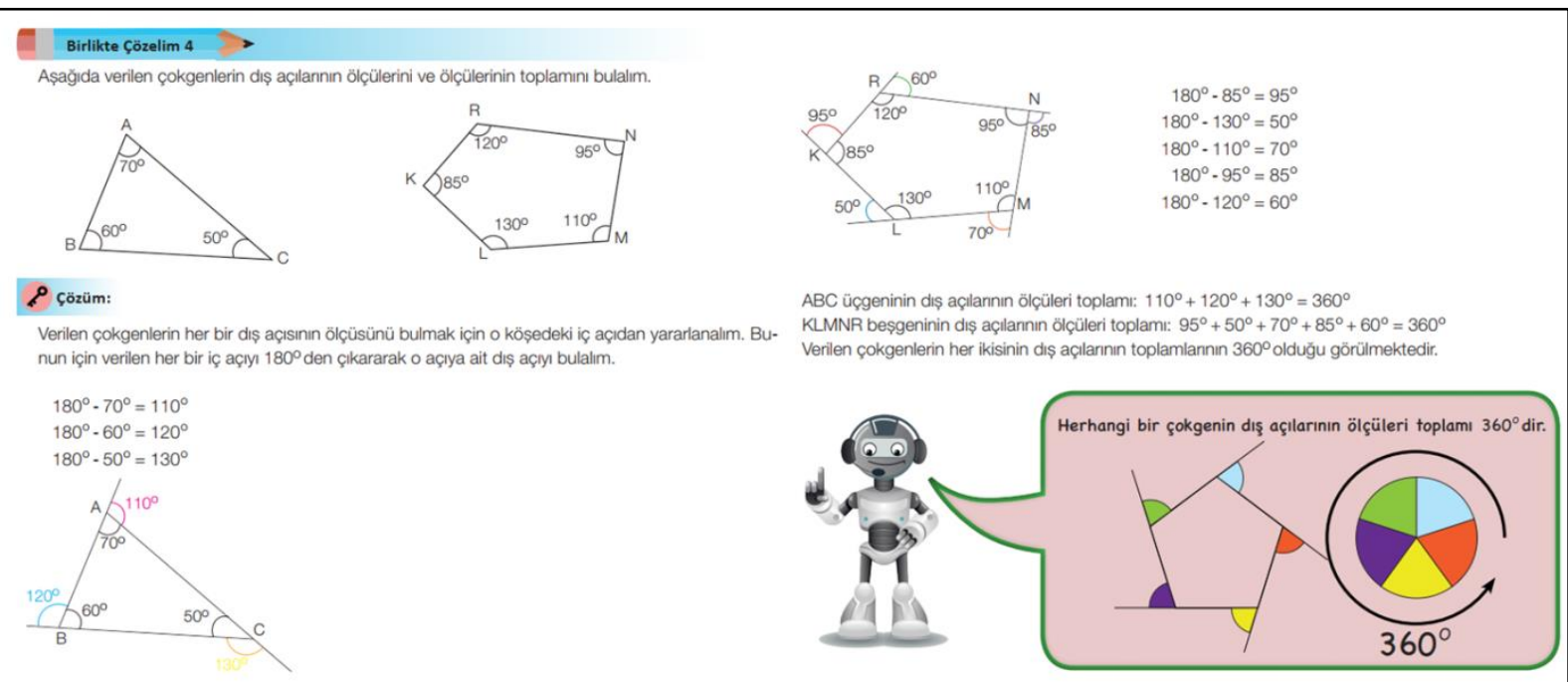

Şekil 8. Yedinci sınıf MEB yayınevinde yer alan çözümlü örnek

Yedinci sınıf matematik kitaplarında bazı çözümlü örneklerin, matematiksel formüller verildikten sonra, formülün doğrudan kullanılmasına yönelik olduğu görülmüştür (bkz. Şekil 9). Bu tarz örnekler herhangi bir düşünme alışkanlığı kullanmayı gerektirmediğinden, araştırmacılar tarafindan alışkanlık yok şeklinde kodlanmıştır.

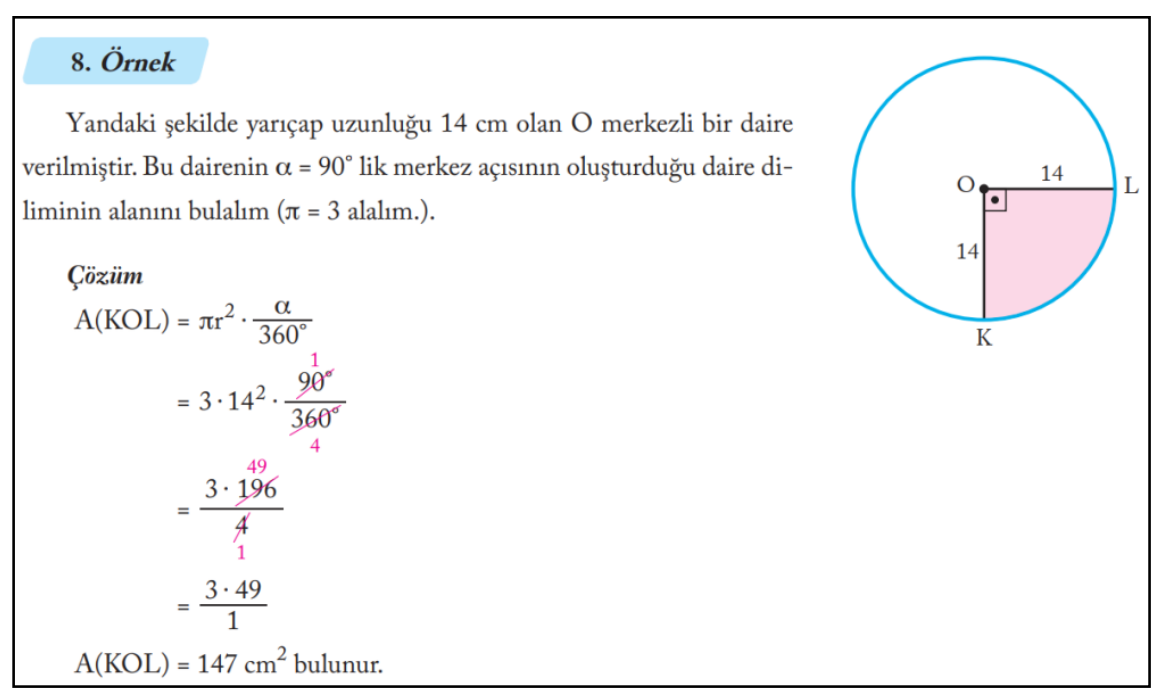

Şekil 9. Yedinci sınıf Ekoyay yayınevinde yer alan çözümlü örnek

Şekil 9'da daire diliminin alanının doğrudan bulunmasına yönelik çözümlü bir örnek verilmiştir. Özellikle Ekoyay yayınevinde bu türden çözümlü örneklere sık rastlanmıştır. Bu tarz örneklerin çözümü yapılırken doğrudan matematiksel formüllerden yararlanıldığından, çözüm sürecinde herhangi bir alışkanlık kullanımına rastlanmamıştır.

\subsection{Sekizinci Sınıf Matematik Ders Kitaplarında Yer Alan Çözümlü Örneklerin Analizi}

Sekizinci sınıf matematik ders kitaplarında yer alan çözümlü örneklerin GDA kullanımına yönelik analizine Tablo 6'da yer verilmişsir.

Tablo 6. Sekizinci sınıf matematik ders kitaplarında yer alan çözümlü örneklerin analizi

\begin{tabular}{|c|c|c|c|c|c|c|c|c|c|c|c|}
\hline & & \multicolumn{2}{|c|}{ İlişkilendirme } & \multicolumn{2}{|c|}{$\begin{array}{c}\text { Geometrik Fikirleri } \\
\text { Genelleme }\end{array}$} & \multicolumn{2}{|c|}{$\begin{array}{l}\text { Değişmezleri } \\
\text { Araștırma }\end{array}$} & \multicolumn{2}{|c|}{$\begin{array}{c}\text { Keşfetme ve } \\
\text { Yansitma }\end{array}$} & \multicolumn{2}{|c|}{$\begin{array}{c}\text { Alışkanlık } \\
\text { Gözlenmedi } \\
\end{array}$} \\
\hline & & $\mathrm{f}$ & $\%$ & $\mathrm{f}$ & $\%$ & $\mathrm{f}$ & $\%$ & $\mathrm{f}$ & $\%$ & $\mathrm{f}$ & $\%$ \\
\hline \multirow{3}{*}{ 8. $\sin 1 f$} & MEB 1 & 46 & 54.77 & 6 & 7.14 & 7 & 8.33 & 24 & 28.57 & 1 & 1.19 \\
\hline & MEB 2 & 23 & 56.12 & 6 & 14.63 & 2 & 4.87 & 9 & 21.95 & 1 & 2.43 \\
\hline & KÖK-E & 27 & 52.95 & 3 & 5.88 & 4 & 7.84 & 17 & 33.33 & 0 & \\
\hline
\end{tabular}


Tablo 6 incelendiğinde Kök-e yayınevinde yer alan çözümlü örneklerin \%52.94'ünde ilişkilendirme, \%33.33'ünde keşfetme ve yansıtma, \%7.84'ünde değişmezleri araştırma, \%5.88'inde geometrik fikirleri genelleme alışkanlıklarının kullanıldığı görülmektedir. MEB 2 yayınevinde yer alan çözümlü örneklerin ise \%56.09'unda ilişkilendirme, \%21.95'inde keşfetme ve yansıtma, \%14.63'ünde geometrik fikirleri genelleme, \%4.87'sinde ise değişmezleri araştırma alışkanlıkları kullanılmıştır. Buna ek olarak \%2.43'ünde ise herhangi bir geometrik düşünme alışkanlığının kullanımına rastlanmamıştır. Son olarak MEB 1 yayınevinde yer alan çözümlü örneklerin \%54.76'sının ilişkilendirme, \%28.57'sinin keşfetme ve yansıtma, \%8.33'ünün değişmezleri araştırma, \%7.14'ünün geometrik fikirleri genelleme alışkanlığına yönelik olduğu görülmektedir. Ayrıca \%1.19'unda ise herhangi bir geometrik düşünme alışkanlığının kullanımına rastlanmamıştır.

GDA'lar sekizinci sınıf matematik ders kitaplarında yer alan çözümlü örneklerde bazen tek bazen de birkaç alışkanlık birlikte olacak şekilde kullanılmıştır. Şekil 10'da ilişkilendirme, keşfetme ve yansıtma, geometrik fikirleri genelleme alışkanlıklarının birlikte kullanımına yönelik bir örnek verilmiştir.

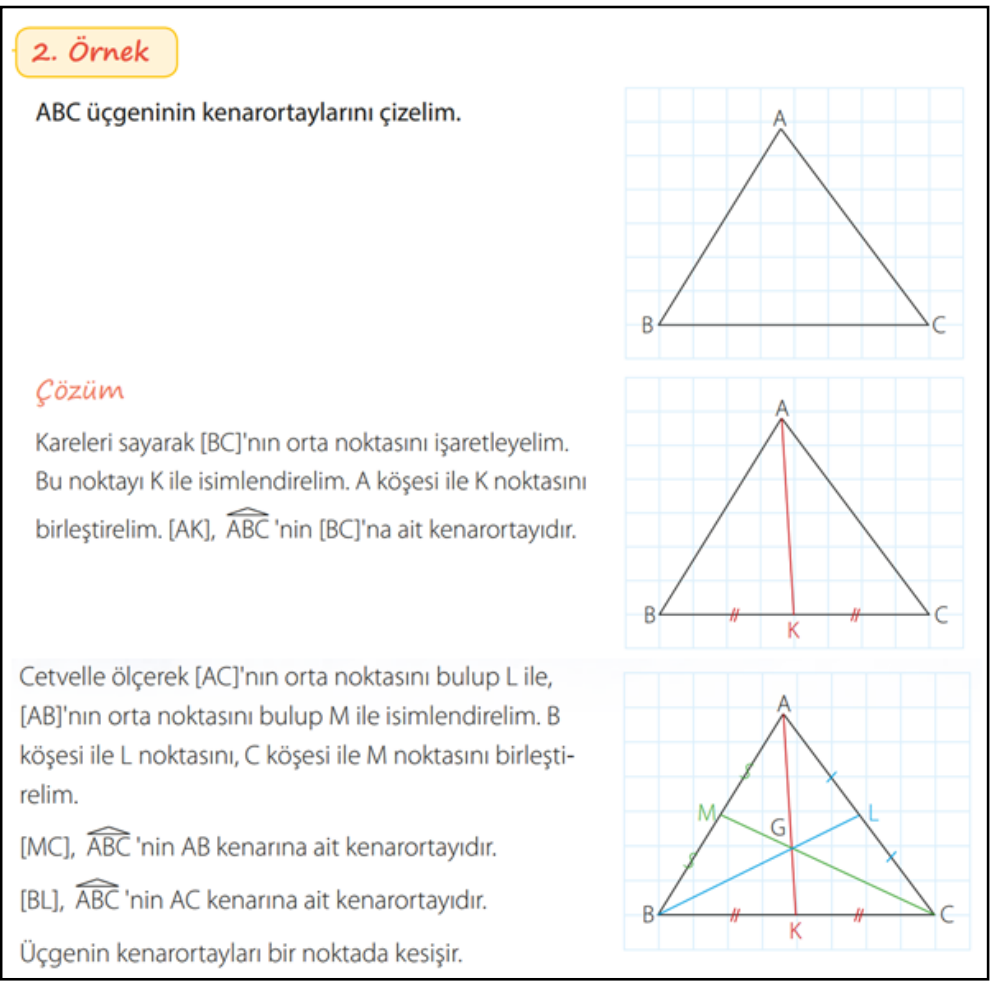

Şekil 10. Sekizinci sınıf Kök-e yayınevinde yer alan çözümlü örnek

Şekil 10’da üçgenlerin kenarortaylarının çizilmesine yönelik bir örnek verilmiştir. Bu örnekte öncelikle A köşesinden çizilen kenarortay daha sonra sırasıyla B ve C köşelerinden çizilen kenarortaylar şekil üzerinde gösterilmiştir. Daha sonra bütün kenarortayların bir noktada kesiştiğine vurgu yapılmıştır. Bu çözümde şekil üzerinde ek çizimler yapıldığından keşfetme ve yansıtma, özel durumların doğruluğundan yararlanarak genel bir kural oluşturulduğundan geometrik fikirleri genelleme ve kenarortaylar ile kenarların ilişkilendirilmesi yapıldığından ilişkilendirme alışkanlığı kullanılmıştır. Bazı çözümlü örneklerde ise ilişkilendirme alışkanlığı tek başına kullanılmıştır (Bkz. Şekil 11).

\section{2. Örnek}

Aşağıdaki üçgenlerde, verilmeyen kenar uzunluklarının alabileceği doğal sayı değerlerini belirleyelim. a)

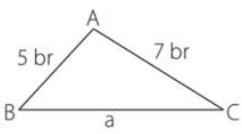

c)

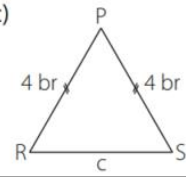

b)

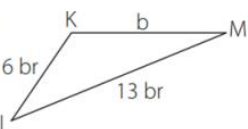

Şekil 11. Sekizinci sınıf Kök-e yayınevinde yer alan çözümlü örnek

\section{çozum}

Verilmeyen kenar uzunlukları diğer kenar uzunluklarının toplamından küçük, farkının mutlak değerinden büyük olmalıdır.

a) $7+5=12>$ a $|7-5|=2<$ a olduğundan a; 2'den büyük, 12 'den küçük olmalıdır. O hâlde $a ; 3,4,5,6,7,8,9$, 10 ve 11 doğal sayı değerlerini alabilit.

b) $13+6=19>$ b $|13-6|=7<$ b olduğundan $b ; 8,9,10,11,12,13,14,15,16,17$ ve 18 doğal sayı değerlerini alabilir.

c) $4+4=8>c|4-4|=0<$ c olduğundan c; $1,2,3,4,5$, 6 ve 7 doğal sayı değerlerini alabilir. 
Şekil 11'de üç farklı üçgen ve kenar uzunlukları verilmiştir. Öğrencilerden istenilen bu uzunlukları göz önünde bulundurarak üçgenlerin çizilip çizilemeyeceği hakkında yorum yapmasıdır. Örneğin çözümü incelendiğinde "bir üçgenin çizilebilmesi için verilmeyen kenar uzunlukları diğer kenar uzunluklarının toplamlarından küçük, farkının mutlak değerinden büyük olmalıdır” önermesinden yola çıkıldığı görülmektedir. Dolayısıyla bu çözümde üçgenler ile kenar uzunlukları arasında ilişkilendirme yapılarak bir sonuca ulaşıldığı görülmektedir. Bu çözüm sürecinde de ilişkilendirme alışkanlığı tek başına kullanılmıştır.

\section{Tartışma, Sonuç ve Öneriler}

Bu çalışmada 2020-2021 öğretim y1lı itibariyle okutulması kabul edilmiş matematik ders kitaplarının çokgenler ve alan ölçme konularında kullandıkları çözümlü örneklerin GDA’lar kapsamında incelenmesi amaçlanmıştır. $\mathrm{Bu}$ amaç doğrultusunda doküman analizi yöntemi kullanılarak ilköğretim kademesinde yer alan bütün matematik ders kitapları incelenmiştir. Ders kitaplarında en çok örnek çözümlere sırasıyla yedinci, sekizinci, altıncı ve beşinci sınıflarda rastlanmıştır. Örneklerin fazla olması GDA'ların gelişimi bakımından oldukça önemlidir (Driscoll vd., 2007; Driscoll vd., 2008, Cuoco vd.1996). Dolayısıyla yedinci ve sekizinci sınıfta yer alan çözümlü örneklerin GDA'ların ve problem çözme başarısının artması bağlamında önemli bir yeri olduğu söylenebilir. Lliteratürde matematik ders kitaplarında yer alan örnek ve problemlerin fazlalığı ve farklı çözüm yollarına hitap etmesi, öğrencilerin konuyu anlamasında etkili olduğunu vurgulamaktadır (Kwon, Park ve Park, 2006; Sawada, 1997). Driscoll vd. (2007) tarafindan da ifade edildiği gibi fazla sayıda örnek çözülmesi öğrencilerin GDA'larını tecrübeli bir şekilde kullanmasına yardımcı olmaktadır. Dolayısıyla ders kitaplarında yer alan çözümlü örnek sayısının artması hem öğrencilerin problem çözme süreçlerini olumlu etkileyecek hem de GDA'ları farkındalık düzeyinde kullanmasına yardımcı olacaktır. Ama bu alıştırma türünden soruların çok sorulması, öğrencilerin alışkanlıklarını olumlu etkiler anlamına gelmez. Yani GDA'lar, bireylerin zor bir problemle karşılaştığında problemin çözümüne yönelik yaklaşımlarıdır tanımında olduğu gibi, öğrencilere rutin olmayan problemlerin çokça sorulması onların söz konusu alışkanlıklarını harekete geçirmede yardımcı olacaktır. Örneğin yedinci sınıf Ekoyay yayınevinde çokgenler ile ilgili 70 çözümlü örnek soru yer almaktadır. Ancak bu örneklere bakıldığında çoğunluğunun alıştırma niteliğinde rutin problemler şeklinde olduğu görülmektedir. Yine bu örneklerin çözümlerinin çoğunluğunda alışkanlık gözlenmediği fark edilmektedir. $\mathrm{O}$ halde öğrencilere sadece alıstırma türünde soruların çok sorulması, GDA'larını harekete geçirmede sinırlı kalabilmektedir yorumu yapılabilir. Burada unutulmaması gereken nokta, örnek sayılarının fazlalı̆̆ kadar; farklı düşünme alışkanlıklarının kullanımını gerektiren sorulara mümkün olduğunca yer verilmesidir. Farklı düşünme alışkanlıklarının göstergelerini temsil edecek farklı tipteki sorulara yer vermek; öğrencilerin geometrik bakış açılarının geliştirilmesine katkı sağlayacaktır.

GDA'ların kullanımı bakımından incelendiğginde, bütün sınıf seviyelerinde ve yayınevlerinde ilişkilendirme alışkanlığının en yüksek düzeyde kullanıldığı görülmektedir. Bir geometri probleminin çözüm sürecinde ilişkilendirme ile keşfetme ve yansıtma alışkanlıkları oldukça önemlidir. İlişkilendirme ile keşfetme ve yansıtma alışkanlığının göstergelerinde geometrik şekillerde ek çizim yapma, üçgende alan-kenar uzunluğu arasında ilişki kurma, farklı açılı üçgenlerde yükseklik çizme, geometrik şekillerin özelliklerini birbiri ile karşılaştırma gibi konularda söz konusu alışkanlıklar kullanılabilmektedir. Bu bağlamda öğrencilerin ilköğretim düzeyinde ilişkilendirme ile keşfetme ve yansıtma alışkanlıklarının geliştirilmesinin karşılaşılan problemlerin çözümünde önemli bir yer oluşturduğu söylenebilir. Çünkü öğrenciler, karşılaş̧tı̆ı geometrik şekiller arasında ne kadar iyi düzeyde ilişki kurabilirse, problemlerin çözümünde önceden öğrendiği geometrik yapıları yeni öğrendikleri ile o kadar iyi iliş̧kilendirebilecek ve karşılaştı̆̆ı problemlere o kadar iyi çözümler üretebilecektir (Cuoco, Goldenberg ve Mark, 1996; Driscoll ve diğerleri, 2007; Leikin, 2007; Seago, Jacobs, Driscoll, Nikula, Matassa ve Callahan, 2013). Bu nedenledir ki; Cuoco, Goldenberg ve Mark (1996) düşünme alışkanlıklarına dayalı geliştirdiği öğretim programında öğrencilerde en temel bulunması gereken matematiksel ve GDA'ların birinin ilişkilendirme alışkanlığı olduğunun üzerinde durmuştur. Yine çözümlü örneklerin pek çoğunda keşfetme ve yansitma alışkanlığının göstergelerinden biri olan "problemin çözümüne yardımcı olabilecek ek bir çizim yapma" alışkanlığının kullanıldığı görülmektedir. Ek çizim yapmaya yönelik örneklerde öğrenciler hem kavramlar arasında ilişki kurma hem de geometrik şekillerindeki yapıları keşfetmeye yönlendirici niteliktedir. Dolayısıyla geometri probleminin çözümü için yapılan ek çizimler, öğrencileri geometrik yapılar arasında ilişki kurmaya yönlendirip problem çözme sürecine yardımcı olacaktır. Bununla birlikte dikkat çeken diğer husus ise; matematik ders kitaplarının çoğunda keşfetme ve yansıtmanın diğer göstergelerinin kullanılacağı örneklere çok rastlanmamış olmasıdır. Özellikle keşfetme ve yansıtma alışkanlığının önemli göstergelerinden biri olan "problemin çözümünün yapılamadığı durumlarda farklı çözüm stratejileri geliştirme" alışkanlığının kullanılabileceği örnek problemlere yer vermek; diğer geometri problemlerin çözümüne yeni bir bakış kazandırması açısından önemlidir.

Matematik ders kitaplarında yer alan çözümlü örneklerin çoğunun merkezinde ilişkilendirme ile keşfetme ve yansıtma alı̧kanlığının birlikte kullanıldığ 1 görülmektedir. Çözümlü örneklerin incelemesini detaylandırdığımızda Driscoll vd. (2007) tarafindan verilen örneklerde olduğu gibi izometrik/noktal/kareli kâğıt kullanımlarında genellikle ilişkilendirme ile keşfetme ve yansıtma alışkanlığı kullanılmaktadır. Çünkü bu 
kağıtlar yeni bir geometrik şeklin çizimine ve şekil ile kenar uzunlukları/alan/çevre ilişkilendirmesini yapmaya yönlendirmektedir. Pergel kullanmaya yönelik örneklerde ve kâğıt katlamalı örneklerde ise ilişkilendirme, değişmezleri araştırma ile keşfetme ve yansıtma alışkanlıkları genel olarak bir arada kullanılmıştır. Bunun dışında farklı durumların doğruluğunu göstererek genel bir kural ya da örüntü bulmaya yönelik örneklerde GDA'ların hepsinin bir arada kullanıldığı görülmüştür.

Matematik ders kitapları incelendiğinde dikkat çeken bir diğer durum; değişmezleri araştırma alışkanlığının kullanımına yönelik örneklerin azlığıdır. Bu alışkanlığın kullanımını gerektiren örnekler incelendiğinde kesip yapıştırma ya da katlamaya yönelik etkinliklere yer verildiği görülmektedir. Bununla birlikte; literatür incelendiğinde öğrencilerin özellikle geometride değişen/değişmeyen yapıları inceleme, dinamik düşünme sürecinde dinamik geometri yazılımlarının etkili olduğu görülmektedir (Cuoco vd., 2010; Kılıç, 2013; Seago, Jacobs, Heck, Nelson ve Malzahn, 2015). Bu bağlamda ders kitaplarında buna yönelik örnek etkinliklerin artırılması bu alışkanlığın geliştirilmesinde rol oynayacağı gibi; geometride teknolojiden de etkin bir biçimde yararlanmalarını sağlayacaktır. Yine, ders kitaplarındaki örneklerde geometrik fikirlerin genelleştirilmesi alışkanlığının beşinci sınıf düzeyinde nadir kullanıldığı; diğer sınıf düzeylerinde ise az miktarda kullanıldığ görülmektedir. Örneklerin bir kısmında olası tüm durumların düşünülerek bir kısmında ise özel bir durumdan genele uyarlanarak bu alışkanlığın kullanıldığı dikkat çekmektedir.

Matematik ders kitaplarında yer alan çözümlü örnekler sınıflara göre incelendiğinde en az çözümlü örneğin beşinci sınıf düzeyinde en çok çözümlü örneğin ise yedinci ve sekizinci sınıf düzeyinde olduğu görülmektedir. $\mathrm{Bu}$ durumun sebeplerinden birinin yedinci ve sekizinci sınıf düzeyinde öğrencilerin birtakım sınavlara hazırlık yapması gerekliliğinden kaynaklanabileceği düşünülmektedir. Buna ek olarak öğrencilerin gelişim düzeyleri ne kadar artarsa problem çözebilme yeteneklerinin de o ölçüde geliştiği ifade edilebilir. Ayrıca bütün sınıf düzeylerinde MEB 'de (2018) belirtildiği gibi bilgisayar yazılımlarının kullanıldığı örnekler yer almaktadır. Ancak beşinci sınıf düzeyinde yer alan bu tür örnekler öğrenciyi etkili çözüm yapmasına engel olabilmektedir. Yani adım adım öğrenciye ne yapılacağının anlatılması ve yazılım hakkında herhangi bir açıklama yapılmaması öğrencileri GDA kullanımdan uzaklaştırabilmektedir. Bu durumun aksine ders kitaplarında yer alan bilgisayar destekli örneklerin, öğrencileri soyut kavramları somutlaştırılmasına yardımcı olması gerekir. Çünkü soyutlama becerisinin gelişimi öğrencilerin problem çözme becerilerinin gelişimini de etkilemektedir (Kılıçoğlu, 2020). Problem çözme becerilerinin gelişimi de GDA kullanımını da olumlu etkilediğinden (Bülbül ve Güven, 2019; Bülbül ve Güven, 2020), yazılımların çözümlü örneklerde etkili kullanılması önemlidir.

$\mathrm{Bu}$ çalışmada her sınıf seviyesine göre ve her yayınevine göre, ortaokul matematik ders kitaplarının üçgenler ve dörtgenler, alan ölçme, çokgenler ile üçgenler ünitesine ait bölümleri GDA kullanımı bağlamında incelenmiştir. Araştırmada baz alınan çözümlü örnek sayıları ve GDA kullanım sayısı dikkate alınarak; öğretmenlerin derslerinde kullanacakları kitapların seçiminde bu çalışmanın bir referans olabileceği öngörülebilir. Yani öğretmenler derslerinde işleyeceği kitapları seçerken kitaplarda çok fazla alıştırma türünden soruların olmasından ziyade, çözümlü örneklerin açıklayıcı ve kavramları destekleyici nitelikte olmasına dikkat etmelidir. Bunu sağlamanın yollarından biri de örneklerde yer alan çözümlerin farklı GDA'lara hitap etmesi baz alınabilir. Dolayısıyla, öğretmenlerin ders anlatım sürecinde tercih ettikleri kaynak/kaynaklarda yer alan örnek etkinlik tercihleri sorgulanabilir. Yine, farklı sınıf düzeyindeki ortaokul öğrencilerinin örnek çözümlü sorularda yer alan GDA' ları hangi oranda kazandıkları ve bu süreçte yaşadıkları problemler derinlemesine incelenebilir.

Etik Kurulu Raporu: Araştırma kapsamında ULAKBİM TRDİZIN kriterleri çerçevesinde (veri kaynağı olarak ders kitapları kullanıldığı ve doküman analizi gerçekleştirildiği için) etik kurul raporu gerekmemektedir.

Ek 1. Analize dâhil edilen kitapların kapak sayfaları

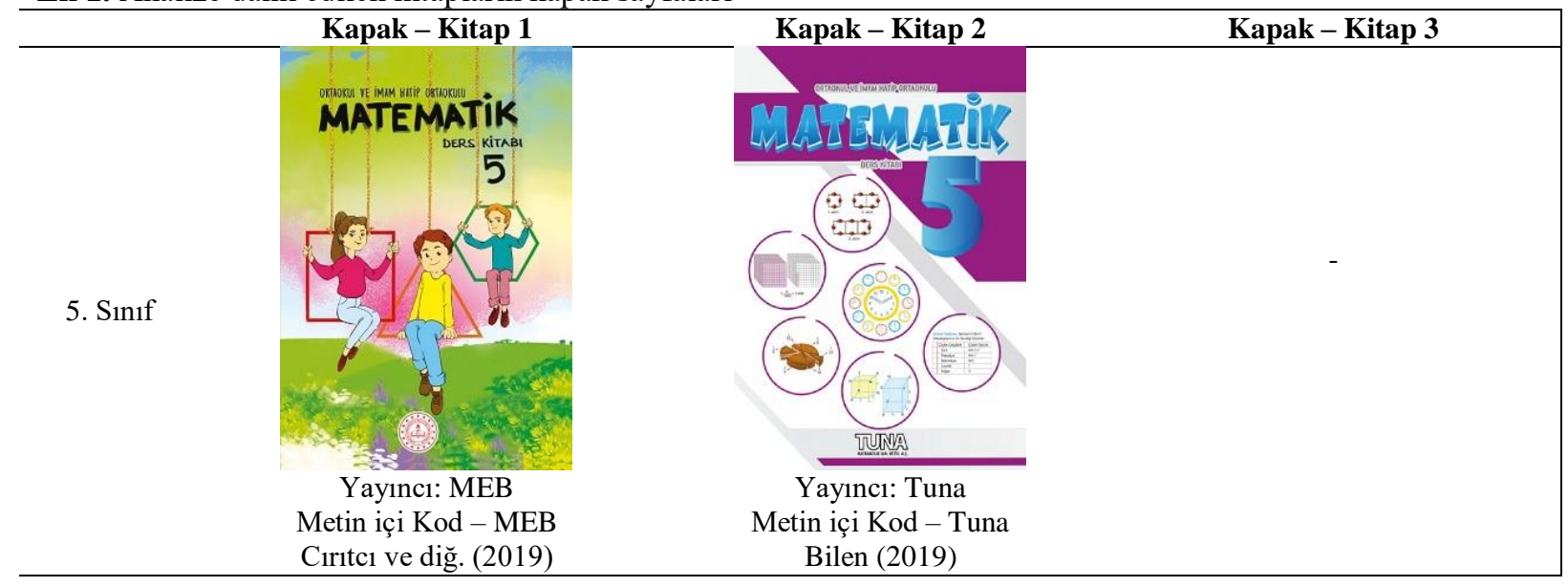


Ek 1'in devam

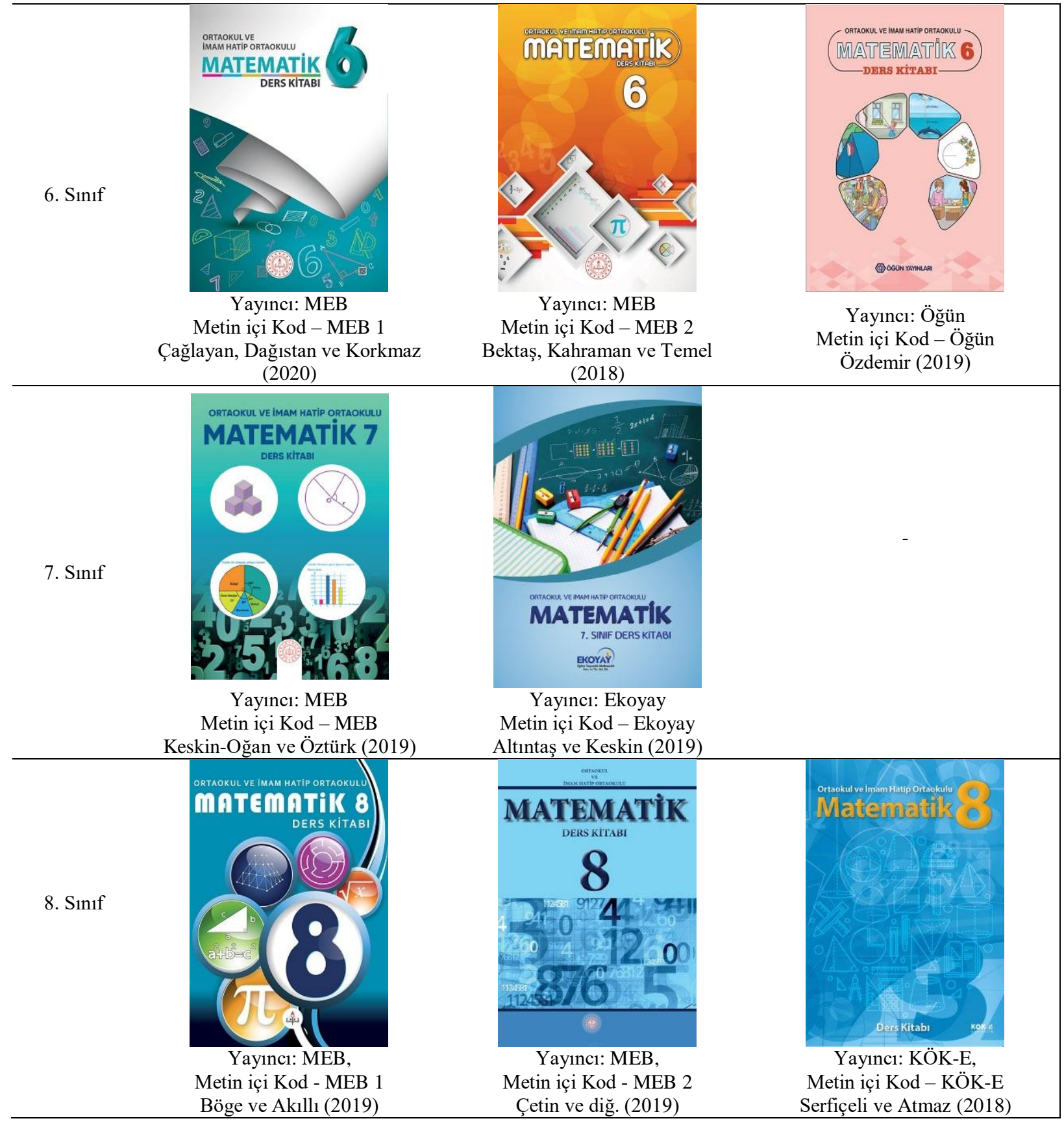

\section{Kaynaklar/References}

Akdeniz, A. R. (2004). Konu alanı ders müfredatı incelenmesi dersinde yürütülen etkinlikler ve kazandırılan davranışların değerlendirilmesi. Eğitim ve Bilim, 29(134), 11-18.

Alkan, S. ve Güven, B. (2018). Ders kitaplarında kullanılan örnek türlerinin analizi: Limit konusu. Türk Bilgisayar ve Matematik Eğitimi Dergisi, 9(1), 147-169.

Altıntaş, Ş. ve Keskin, C. (2019). Ortaokul ve İmam Hatip Ortaokulu Matematik 7. Sınıf ders kitabı. Ankara: Ekoyay Eğitim Yayıncılık.

Altun, M., Arslan, Ç. ve Yazgan, Y. (2004). Lise matematik ders kitaplarının kullanım şekli ve sıklığı üzerine bir çalışma. Uludă̆ Üniversitesi Ĕ̈itim Fakültesi Dergisi, 17(2), 131-147.

Bektaş, M., Kahraman, S. ve Temel, Y. (2018). Ortaokul ve İmam Hatip Ortaokulu Matematik ders kitabı 6. Ankara: Milli Eğitim Bakanlı̆̆ Yayınları.

Bilen, O. (2019). Ortaokul ve Imam Hatip Ortaokulu Matematik ders kitabı 5. Ankara: Tuna Matbaacilık.

Bingölbali, E. ve Bingölbali, F. (2020). An examination of tasks in elementary school mathematics textbooks in terms of multiple outcomes and multiple solution methods. International Journal of Educational Studies in Mathematics, 7(4), 214-235. 
Böge, H. ve Akıllı, R. (2019). Ortaokul ve Imam Hatip Ortaokulu Matematik 8 ders kitabı. Ankara: Milli Ĕgitim Bakanlığ 1 Yayınları.

Bülbül, B. Ö. (2016). Matematik öğretmeni adaylarının geometrik düşünme alışkanlıklarını geliştirmeye yönelik tasarlanan ögrenme ortamının değerlendirilmesi (Yayınlanmamış doktora tezi). Karadeniz Teknik Üniversitesi, Eğitim Bilimleri Enstitüsü, Trabzon.

Bülbül, B. Ö. ve Güven, B. (2019). Geometrik düşünme alışkanlıkları ile akademik başarı arasındaki ilişkinin incelenmesi: Matematik öğretmeni adayları örneği. Türk Bilgisayar ve Matematik Eğitimi Dergisi, 10(3), 711-731.

Bülbül, B.Ö. \& Güler, M. (2021). Can geometry achievement and geometric habits of mind be improved online? reflections from a computer- aided intervention. Journal of Educational Technology. Advanced online publication. https://doi.org/10.1177/0047239520965234

Bülbül, B.Ö. ve Güven, B. (2020). Öğretmen adaylarının geometrik düşünme alanlarının değişimi. Pamukkale Üniversitesi Eğitim Fakültesi Dergisi,48, 431-453. doi: 10.9779/pauefd.513220.

Bütüner, S. Ö. (2020). Türkiye'de okutulan ortaokul matematik ders kitaplarının aritmetik ortalama kavramına ilişkin öğrencilere sunduğu öğrenme firsatları. Türk Bilgisayar ve Matematik Eğitimi Dergisi, 11(1), 157187.

Cirıtcı, H., Gönen, İ., Araç, D., Özarslan, M., Pekcan, N. ve Şahin, M. (2019). Ortaokul ve Imam Hatip Ortaokulu Matematik ders kitabı 5. Ankara: Milli Eğitim Bakanlığı Yayınları.

Costa, A. L., \& Kallick, B. (2009). Habits of mind across the curriculum: Practical and creative strategies for teachers. Association for Supervision and Curriculum Development.

Cuoco, A., Goldenberg, E. P., \& Mark, J. (1996). Habits of mind: An organizing principle for mathematics curricula. The Journal of Mathematical Behavior, 15(4), 375-402.

Çağlayan, N., Dağıstan, A. ve Korkmaz, B. (2020). Ortaokul ve Imam Hatip Ortaokulu Matematik ders kitabı 6. Ankara: Milli Eğitim Bakanlığı Yayınları.

Çelik, T., Çetinkaya, G. ve Aydoğan-Yenmez, A. (2020). Ortaokul matematik ders kitaplarındaki metinlerin okunabilirliği ve anlaşılabilirliği üzerine öğretmen-öğrenci görüşleri. Ankara Üniversitesi Ĕgitim Bilimleri Fakültesi Dergisi, 53(1), 1-28.

Çetin, Ö., Aksakal, U., Ertürk, Ü., Şay, G. ve Tığlı, İ. (2019). Ortaokul ve İmam Hatip Ortaokulu Matematik 8 ders kitabı. Ö. Çetin (Ed). Ankara: Milli Ĕ̆itim Bakanlığ 1 Yayınları.

Đokić, O. J. (2018). Research perspectives of initial geometry education. Journal of Pedagogical Research, 2(2), 102-111.

Driscoll, M. J., DiMatteo, R. W., Nikula, J., \& Egan, M. (2007). Fostering geometric thinking: A guide for teachers grades 5-10. Heinemann.

Driscoll, M. J., DiMatteo, R. W., Nikula, J., Egan, M., Mark, J., \& Kelemanik, G. (2008). The fostering geometric thinking toolkit: A guide for staff development. Heinemann.

Erşen, Z.B. (2018). Onuncu sınıf öğrencilerinin geometrik düşünme alışkanlıklarını geliştirmeye yönelik öğretim ortamının tasarlanması, uygulanması ve değerlendirilmesi (Yayımlanmamış doktora tezi). Uludağ Üniversitesi, Eğitim Bilimleri Enstitüsü, Bursa.

Fan, L. (2013). Textbook research as scientific research: towards a common ground on issues and methods of research on mathematics textbooks. ZDM, 45(5), 765-777.

Goldenberg, E. P. (1996). "Habits of Mind" as an organizer for the curriculum. Journal of Education, 178(1), $13-34$.

Gordon, M. (2011). Mathematical habits of mind: Promoting students' thoughtful considerations. Journal of Curriculum Studies, 43(4), 457-469.

Herbel-Eisenmann, B. A. (2007). From intended curriculum to written curriculum: Examining the "voice" of a mathematics textbook. Journal for Research in Mathematics Education, 38(4), 344-369.

Keskin-Oğan, A. ve Öztürk, S. (2019). Ortaokul ve Imam Hatip Ortaokulu Matematik 7 ders kitabl. Ankara: Milli Eğitim Bakanlığı Yayınları.

Kılıç, A. ve Seven, S. (2005). Konu alanı ders kitabı incelemesi. Ankara: Pegem A Yayıncılık.

Korkmaz, E., Tutak, T., \& İlhan, A. (2020). Evaluation of secondary school mathematics textbooks by mathematics teachers. European Journal of Science and Technology. 18, 118-128.

Kwon, O. N., Park, J. H., \& Park, J. S. (2006). Cultivating divergent thinking in mathematics through an openended approach. Asia Pacific Education Review, 7(1), 51-61.

Lim, K. H., \& Selden, A. (2009). Mathematical habits of mind. In S. L. Swars, D. W. Stinson \& S. LemonsSmith (Eds.), Proceedings of the 31st annual meeting of the North American Chapter of the International Group for the Psychology of Mathematics Education (pp. 1576-1583). Atlanta: Georgia State University.

Marshall, A. R. (2004). High school mathematics habits of mind instruction: student growth and development (Unpublished master's thesis). Southwest Minnesota State University, USA.

Millî Eğitim Bakanlığ1 [MEB]. (2018). Matematik dersi öğretim programı (İlkokul ve ortaokul 1,2,3,4,5,6, 7 ve 8. sinıflar). Ankara: Millî Eğitim Bakanlığı Yayınları. 
National Council of Teachers of Mathematics [NCTM]. (2000). Principles and standards for school mathematics. NCTM.

Oikonomidis, I. (2018). The promotion of cultivating critical thinking skills in Greek Lyceum: a qualitative content analysis of the first-class Informatics textbook. Journal of Pedagogical Research, 3(1), 24-36. https://doi.org/10.33902/JPR.2019.2

Özdemir, Ç. (2019). Ortaokul ve Imam Hatip Ortaokulu Matematik ders kitabı 6. Ankara: Öğün Yayınları.

Özkaya, F. ve Duru, A. (2020). Ortaokul matematik ders kitaplarında değerler eğitimi kapsamındaki değerlerin yer alma durumlarının incelenmesi. Uşak Üniversitesi Eğitim Araştırmaları Dergisi, 6(3), 43-67.

Sawada, T. (1997). Developing lesson plans. In J. Becker, \& S. Shimada (Eds.), The open-ended approach: A new proposal for teaching mathematics (pp. 23-35). National Council of Teachers of Mathematics.

Schoenfeld, A.H. (1992). Learning to Think Mathematically: Problem Solving, Metacognition and Sense Making in Mathematics. In D.A. Grouws (Ed.), Handbook of research on mathematics teaching (pp.334370). New York: MacMillan Publishing.

Serfiçeli, Z. ve Atmaz, D. (2018). Ortaokul ve Imam Hatip Ortaokulu Matematik 8. Sınıf ders kitabı. Ankara: Kök-e Yayıncılık.

Üredi, L. ve Ulum, H. (2020). İlkokul matematik ders kitaplarında bulunan ünite değerlendirme sorularının yenilenmiş Bloom taksonomisine göre incelenmesi. Mersin Üniversitesi Ĕ̆itim Fakültesi Dergisi, 16(2), 432-447.

Wach, E. \& Ward, R. (2013). Learning about qualitative document analysis. Retrieved from https://opendocs.ids.ac.uk/opendocs/handle/20.500.12413/2989

Yaşar, O. (2005). Türkiye'de okutulan orta öğretim coğrafya ders kitaplarında ölçme ve değerlendirme çalışmalarına yönelik karşılaştırmalı bir yaklaşım. International Journal of Progressive Education, 1(2), 930 .

Yılmaz, A., Seçken, N. ve Morgil, İ. (1998). Lise 11. sınıf kimya 3 ders kitaplarının kimya eğitimine uygunluklarının araştırılması. Hacettepe Üniversitesi Ĕgitim Fakültesi Dergisi, 14(14), 73-83. 